\title{
Ethanol production by engineered thermophiles
}

Daniel G. Olson ${ }^{1,3}$, Richard Sparling ${ }^{2}$ and Lee R. Lynd ${ }^{1,3}$

\begin{abstract}
Addresses
${ }^{1}$ Thayer School of Engineering at Dartmouth College, Hanover, NH 03755, United States

${ }^{2}$ Department of M icrobiology, University of M anitoba, Winnipeg, MB, Canada, R3T 5V6

${ }^{3}$ BioEnergy Science Center, Oak Ridge, TN 37830, United States

Corresponding author: Lynd, Lee R (Lee.R.Lynd@Dartmouth.EDU)

Note on formatting - in order to clarify the differences between genes, proteins and enzymes, names of genes are presented in lower case italic, proteins are presented in title case roman and enzyme activities are presented in all caps.
\end{abstract}

\begin{abstract}
We compare a number of different strategies that have been pursued to engineer thermophilic microorganisms for increased ethanol production. Ethanol production from pyruvate can proceed via one of four pathways, which are named by the key pyruvate dissimilating enzyme: pyruvate decarboxylase (PDC), pyruvate dehydrogenase (PDH), pyruvate formate lyase (PFL), and pyruvate ferredoxin oxidoreductase (PFOR). For each of these pathways except PFL, we see examples where ethanol production has been engineered with a yield of $>90 \%$ of the theoretical maximum. In each of these cases, this engineering was achieved mainly by modulating expression of native genes. We have not found an example where a thermophilic ethanol production pathway has been transferred to a nonethanol-producing organism to produce ethanol at high yield. A key reason for the lack of transferability of ethanol production pathways is the current lack of understanding of the enzymes involved.
\end{abstract}

\section{Introduction}

There is broad consensus that biomass has an important role to play in a low-carbon energy future [1], and that transport fuels are among the highest priority uses for biomass [2]. Ethanol is the biofuel produced in the largest amounts today worldwide, with essentially all resulting from fermentation by the mesophilic yeast Saccharomyces cerevisiae or closely-related species [3].

Ethanol production using thermophilic bacteria has been suggested based on several factors. The property of thermophiles for which there is the strongest case for economic impact is the ability of some microbes from this group to rapidly ferment cellulosic biomass without added enzymes [4,5]. In addition, processing at elevated temperatures reduces the extent of heat exchange, both following pretreatment and prior to distillation, and may reduce the risk of contamination [4]. 
Notwithstanding the interest in thermophiles, most organisms in this class do not naturally carry out a homoethanol fermentation, and do not naturally exhibit high product tolerance. Strain development, often involving metabolic engineering, is required in order to address these deficiencies. This in turn requires advances in understanding the underlying metabolism of thermophilic microbes. As we make progress in strain development, we are learning that the metabolism of thermophilic anaerobes is more complex and more distinctive than previously imagined.

In this report we review recent understanding of the metabolism of thermophilic microbes, focusing primarily but not exclusively on anaerobes that ferment cellulose or hemicellulose. Thereafter, we document recent progress toward engineering these microbes to produce ethanol at high yield, and in some cases titer.

\section{Metabolic pathways of ethanol production in thermophiles}

The native capabilities of thermophilic organisms to produce ethanol have been reviewed recently [6-9] and (Ana Faria Tomás, PhD thesis, Technical University of Denmark 2013) . In this work we will focus only on those thermophilic organisms that have been engineered for increased ethanol production. This includes several obligate anaerobic bacteria: Thermoanaerobacterium saccharolyticum, Thermoanaerobacter ethanolicus, Thermoanaerobacter mathranii, Clostridium thermocellum and Caldicellulosiruptor bescii, the facultative anaerobic bacterium Geobacillus thermoglucosidasius, the anaerobic archaeon Pyrococcus furiosus and the methylotrophic yeast Ogataea polymorpha. All of the organisms described above have had their genomes sequenced, allowing basic metabolic reconstructions to be performed computationally [10].

Compared to a decade ago, understanding of converting pyruvate and various electron carriers into fermentation products has deepened substantially. Moreover this conversion is now known to be more complicated than formerly thought, particularly with respect to redox reactions. As might be expected given these observations, results of efforts to enhance ethanol production in thermophilic microorganisms via targeted molecular modifications have often not yielded the results predicted or desired. There are two key problems:

1. Although we have a good general understanding of the individual steps in fermentation pathways that lead to ethanol production, we do not fully understand the complex interactions between these various pathways.

2. For a given reaction, we do not know which gene or genes are responsible due to inaccuracies in annotation and apparent functional redundancies within the genomes.

M ost organisms, like the ones discussed above, live in complex microbial communities where readily metabolized organic matter is a rather scarce commodity that requires solubilization of complex substrates [11]. This has led to the development of multiple fermentation branches leading to different end-products. The thermodynamic efficiency of a given pathway can vary depending on a variety of factors, including concentrations of cofactors such as NAD+, NADP ${ }^{+}, \mathrm{NADH}, \mathrm{NADPH}$, Acetyl-CoA, HS-CoA, $A M P, A D P, A T P$, and $P_{\mathrm{i}}$, as well as the concentration of carbon intermediates and end-products. The 
thermodynamics of the reactions are further modulated by both the temperature and the $\mathrm{pH}$ of the medium [10]. Figure 1 illustrates the various pathways of pyruvate dissimilation in the organisms discussed. It is hypothesized that the different pathways are necessary in order to provide metabolic flexibility.

One way to think about individual pathways within a metabolic network is by considering key elementary modes. The theoretical maximum ethanol yield of all of the organisms described here is one ethanol per pyruvate, and is described by equation 1, where the NADH is assumed to come from the glyceraldehyde-3-phosphate dehydrogenase (GAPDH) reaction of glycolysis.

(1) Pyruvate $+\mathrm{NADH} \rightarrow$ ethanol $+\mathrm{CO}_{2}$

For the network shown in Figure 1, there are four elementary modes that allow ethanol production at the theoretical maximum, and are described by the various combinations of the following enzymes: pyruvate decarboxylase (PDC), pyruvate dehydrogenase (PDH), pyruvate formate lyase (PFL), pyruvate ferredoxin oxidoreductase (PFOR), nicotinamide ferredoxin oxidoreductase (NFO), formate dehydrogenase (FDH), aldehyde dehydrogenase (ALDH) and alcohol dehydrogenase (ADH).

Of these enzymes, PDC performs non-oxidative decarboxylation of pyruvate whereas other enzymes (PDH, PFL and PFOR) perform oxidative decarboxylation. Although this an important distinction, in each case there are additional enzymes which can transfer the electrons back to ethanol and thus reaction (1) is valid for all four modes.

The combinations of enzyme activities corresponding to the four elementary modes of high-yield ethanol production are described by equations 2-5.

(2) $\mathrm{PDC}+\mathrm{ADH}$

(3) $\mathrm{PDH}+\mathrm{ALDH}+\mathrm{ADH}$

(4) $\mathrm{PFL}+\mathrm{FDH}+\mathrm{ALDH}+\mathrm{ADH}$

(5) $\mathrm{PFOR}+\mathrm{NFO}+\mathrm{ALDH}+\mathrm{ADH}$

\section{Modes of ethanol production from pyruvate}

Since each mode can be identified by the enzyme used for pyruvate dissimilation (i.e. PDC, PDH, PFL or PFOR), we will use this enzyme name to refer to the whole mode. The PDC mode is frequently found in mesophilic organisms [12,13], however it is much less common in thermophiles (depending somewhat on the definition of a thermophile) and in this study it is only found in 0. polymorpha. Although there are a variety of PDC enzymes with high thermostability [13], attempts to introduce this pathway into thermophilic bacteria have met with limited success $[14,15]$. It has been observed that the PFOR enzymes of some thermophilic archaea exhibit PDC activity [16,17], however none of these organisms have been shown to produce more than trace amounts of ethanol [10].

The PFL mode is not found in any of the high-yielding organisms in this study. Although several organisms have a PFL enzyme, none of them have the formate dehydrogenase (FDH) enzyme needed to transfer electrons from formate to ethanol. This strategy has, however, been used for mesophilic ethanol production [18]. 
The PDH mode is found in G. thermoglucosidasius. Although PDH is found in $\mathrm{C}$. bescii and $\mathrm{O}$. polymorpha as well, both lack the ALDH enzyme necessary to allow ethanol production via this mode (Figure 1), and instead likely use it to generate acetyl-CoA for biosynthesis.

The PFOR mode is found in many obligate anaerobes including: C. thermocellum, T. mathranii, T. ethanolicus and T. saccharolyticum. Organisms using this mode generate reduced ferredoxin. In order to produce ethanol at high yield, electrons from the reduced ferredoxin need to be transferred to nicotinamide cofactors (NAD ${ }^{+}$or $\left.\mathrm{NADP}^{+}\right)$. This can be accomplished by the NAD(P) ${ }^{+}$-ferredoxin oxidoreductase (NFO) enzyme. Here we use NFO (alternatively FNO and FNOR) as a general term covering any reaction that transfers electrons from ferredoxin to a nicotinamide cofactor. Because of the difference in expected electronegativity between ferredoxin and $\mathrm{NAD}^{+}$, or NADP ${ }^{+}$, cells can take advantage of the $\triangle G^{\prime}$ associated with this reaction to drive a thermodynamically unfavorable reaction. There are several classes of coupled NFO enzymes: RNF (rhodobacter nitrogen-fixation) couples the NFO reaction ( $\mathrm{NAD}^{+}$specific) to transport of a $\mathrm{Na}^{+}$or $\mathrm{H}^{+}$ion across the membrane [19], $\mathrm{MBX}$ (membranebound oxidoreductase) also couples the NFO reaction (NADP ${ }^{+}$specific) to transport of $\mathrm{H}+$ across the membrane (note that this has not been confirmed experimentally, but is suggested by protein sequence analysis) [20], NFN (NADH-dependent reduced ferredoxin: $\underline{N_{A D P}}{ }^{+}$oxidoreductase) couples the NFO activity with transhydrogenation (i.e. interconversion of NADH and NADPH) [21]. Typically NFO activity is measured by enzyme assay with viologen dye. Unfortunately this is a somewhat crude measurement, since viologen dyes are known to react with a variety of compounds in addition to ferredoxin.

Determining the exact nature of the coupling often requires intricate biochemical experiments. Therefore the presence of NFO activity is often determined by sequence similarity. C. thermocellum contains an rnf gene cluster, P. furiosus contains an mbx gene cluster [20]. C. thermocellum, T. mathranii, T. ethanolicus and T. saccharolyticum each contain an nfnAB gene cluster [22][23].

\section{The bifunctional AdhE protein}

In organisms using the PFL, PDH or PFOR modes for ethanol production, the ALDH and ADH reactions are commonly mediated by a single protein, AdhE. In fact, the presence of the adhE gene is correlated with ethanol production in many organisms [10]. Furthermore, deletion of adhE has been shown to eliminate anaerobic ethanol production in all organisms where this deletion has been created: $\mathrm{T}$. mathranii [24], Thermoanaerobacterium thermosaccharolyticum [25], C. thermocellum [26], T. saccharolyticum [26] and G. thermoglucosidasius (personal communication with M ichael Danson). Indeed, the weak link appears to be the production of acetaldehyde. Numerous fermentative thermophiles have alcohol dehydrogenases, as is the case in Thermococcus guaymasensis, C. bescii and most other extreme thermophiles, yet they do not have adhE and do not produce ethanol. Thus it appears that the lack of conversion of acetyl-CoA to acetaldehyde (i.e. ALDH activity) is preventing ethanol production in those strains.

The adhE gene is a frequent target for spontaneous mutations in ethanol producing strains. Mutations have been observed in adhE in several Clostridium thermocellum strains adapted for increased ethanol tolerance $[27,28]$, as well as one strain engineered for increased ethanol production by deletion of 
hydrogenase genes [29]. M utations in adhE have also been observed in strains of T. saccharolyticum engineered for increased ethanol production (Zheng et al. unpublished).

AdhE is clearly an interesting target for metabolic engineering. Recently the crystal structure of the ADH domain of the AdhE protein from $\mathrm{G}$. thermoglucosidasius was determined to $2.5 \AA$ resolution [30]. This detailed structure will allow for better predictions of targeted mutations.

\section{Aldehyde ferredoxin oxidoreductase (AOR) pathway}

Of the organisms that produce ethanol from acetyl-CoA, the most common pathway for subsequent ethanol production involves the ALDH reaction, which converts acetyl-CoA to acetaldehyde. There is an alternative pathway, however, where acetyl-CoA is converted to acetate by acetyl-CoA synthetase (ACS,

equation 6 ) and then acetate is converted to acetaldehyde by aldehyde ferredoxin oxidoreductase (AOR, equation 7).

(6) acetyl-CoA +ADP $\rightarrow$ Acetate +CoA + ATP

(7) acetate $+\mathrm{Fd}($ red $) \rightarrow$ acetaldehyde $+\mathrm{Fd}(\mathrm{ox})$

This pathway was first suggested by White et al. in 1989 [31], and later mentioned as a theoretical possibility in Clostridium ljungdahlii [32], however direct evidence of the functioning pathway has only recently been presented [33].

\section{Acetate and ATP production}

We have previously discussed elementary modes that allow for theoretical yield of ethanol production. There are a number of alternative modes for other fermentation products. Equation (8) describes a mode for the production of acetate:

(8) Pyruvate $+\mathrm{NADH} \rightarrow$ acetate $+\mathrm{ATP}+\mathrm{CO}_{2}+2 \mathrm{H}_{2}$

Comparing equations ( 1 ) and (8) shows the tradeoff between ethanol and acetate or $\mathrm{H}_{2}$ production, if electrons are diverted to hydrogen production, additional ATP can be generated by acetate kinase. Further energy can be conserved in the form of a proton motive force through the transfer of electrons from reduced ferredoxin to protons generating $\mathrm{H}_{2}$ via a membrane-integral energy-conserving protontranslocating NiFe-hydrogenase. The generation of $\mathrm{H}_{2}$ from $\mathrm{NAD}(\mathrm{P}) \mathrm{H}$ via a hydrogenase is not thermodynamically favorable, so organisms that produce exclusively acetate, $\mathrm{CO}_{2}$ and $\mathrm{H}_{2}$ (equation 8), couple the transfer of electrons from ferredoxin to $\mathrm{H}_{2}$ with the transfer of electrons from $\mathrm{NADH}$ to $\mathrm{H}_{2}$ via an electron-bifurcating hydrogenase [34].

\section{Amino acid production}

Amino acids are an often-overlooked fermentation end-product. From a redox and carbon balance, the amino acids alanine and valine are equivalent to lactate (i.e. they consume pyruvate and NAD(P)H in a 1:1 ratio). Indeed alanine is a major end-product in wild type Pyrococcus furiosus [35], as well as a range of thermophilic Archaea and Bacteria [36]. Amino acids, including alanine and valine, as significant endproducts have also been observed in C. thermocellum under certain growth conditions [37]. As we use 
molecular techniques to direct flux to a single end product, we need to be mindful of these alternative possibilities.

\section{Metabolic engineering}

For many years, the availability of genetic tools was a major limitation to engineering of thermophilic organisms. Over the past several years, genetic tools have been developed for the engineering of a variety of thermophilic organisms, including examples from the genera Clostridium, Thermoanaerobacterium, Thermoanaerobacter, Geobacillus, Caldicellulosiruptor [7,38-40], Pyrococcus [41], and Ogataea [42]. Technologies are being developed to further broaden the suite of organisms for which molecular engineering is available.

\section{Thermoanaerobacterium saccharolyticum}

T. saccharolyticum is a gram-positive anaerobic thermophile that was originally isolated for its ability to grow on xylan at $\mathrm{pH}<4.5$ [43]. It natively produces ethanol, acetate, lactate, $\mathrm{H}_{2}$ and $\mathrm{CO}_{2}$.

Initial metabolic engineering of T. saccharolyticum JW/YS-485 involved the elimination of lactate production by deletion of the lactate dehydrogenase (ldh) gene, resulting in a $5 \%$ increase in ethanol yield $[44,45]$, Subsequent elimination of acetate production by deletion of phosphotransacetylase (pta) and acetate kinase (ack) resulted in a strain (ALK1) that produced only ethanol with yields of $90-100 \%$ of theoretical. This strain was cultivated in a continuous culture for 3000 hours with increasing feed concentrations to produce strain ALK2, which achieved an ethanol yield of $92 \%$, titer of $33 \mathrm{~g} / \mathrm{l}$ and productivity of $2.2 \mathrm{~g} / \mathrm{l} / \mathrm{h}$ (Table 1) [45]. In strain ALK2, both of the genetic modifications resulted in the chromosomal incorporation of an antibiotic resistance marker. Since only two antibiotic markers were available for $\mathrm{T}$. saccharolyticum at the time, no further modifications could be performed with that strain. To overcome this problem, the Idh and pta-ack deletion strain was reconstructed with a maker recycling strategy [46]. This new strain, M 0355, had similar performance to ALK2, with an ethanol yield of $94 \%$, titer of $25 \mathrm{~g} / \mathrm{l}$ and productivity of $1.13 \mathrm{~g} / \mathrm{l} / \mathrm{h}$ (Table 1 ).

It has been shown that salt accumulation from $\mathrm{pH}$ control is a major factor limiting the growth of Thermoanaerobacterium strains [47]. Although strain M 0355 did not produce significant quantities of organic acids, ethanol production resulted in the acidification of the medium due to uptake of ammonium. To reduce the need for $\mathrm{pH}$ control, the strain was engineered to use urea as a source of nitrogen [48]. This (along with adaptation and mutagenesis of the parent strain, M 0863), enabled strain M 1051 to achieve an ethanol titer of $54 \mathrm{~g} / \mathrm{l}$, while maintaining a yield of $88 \%$ of theoretical (Table 1 ). Further engineering was performed on this strain, including repair of a broken methionine gene and elimination of genes involved in the production of polysaccharide. The resulting strain, M 1442, produced ethanol with a yield of $90 \%$ of theoretical, a titer of $61 \mathrm{~g} / \mathrm{l}$ and a productivity of $2.13 \mathrm{~g} / \mathrm{l} / \mathrm{h}$ (Table 1). It is unclear whether these additional improvements were due to the genetic modifications or changes in fermentation conditions [49].

Another approach to engineering T. saccharolyticum was the deletion of hydrogenases to constrain electron flux. Conversion of pyruvate to acetyl-CoA via PFOR produces reduced ferredoxin (Figure 1). 
The electrons from ferredoxin can either be used for hydrogen production or ethanol production, and theoretically a decrease in hydrogen production should result in an equivalent increase in ethanol production. Deletion of the hfs hydrogenase resulted in $96 \%$ reduction in hydrogen production and $95 \%$ reduction in acetate production, but no change in ethanol production [50]. The organism instead distributed carbon and electron flux to lactate production. Subsequent elimination of lactate production by deleting the Idh gene increased ethanol yield, but it was still only $67 \%$ of theoretical (Table 1 ).

\section{Thermoanaerobacter mathranii}

Although it is a different genus, T. mathranii BG1 (wild type) is an anaerobic thermophile similar in physiology to T. saccharolyticum. It has a strong native ability to produce ethanol, with yields of $62-90 \%$ of the theoretical maximum [24,51,52]. The ethanol yield depends on the carbon source, with mannitol giving the highest yield, followed by xylose and then glucose. Several engineering strategies have been pursued to further increase the ethanol yield. In the wild type strain, the carbon flux not directed to ethanol production is directed to lactate and acetate production. The first strategy was deletion of lactate dehydrogenase in strain BG1 to generate strain BG1L1, which resulted in an improvement in ethanol yield of 3\% [24] to 35\% (Table 1)[52]. This improvement was seen on several different substrates, including glucose, xylose and mannitol.

A second engineering strategy attempted to increase the availability of reducing equivalents by expressing glycerol dehydrogenase ( $g l d A)$ and feeding the strain glycerol in addition to either glucose or xylose [52]. Expression of gldA under control of a constitutive promoter led to a $55 \%$ decrease in ethanol production. Expression of gldA under control of a xylose-inducible promoter, in combination with a deletion of Idh, led to a $20 \%$ increase in ethanol production (compared to the Idh deletion alone). It is difficult to know the relative effect of the difference in promoter (constitutive vs. xylose-inducible) compared with the difference in genetic background (wild type vs. Idh deletion), since the factors were not tested separately. A further confounding factor is that the strains expressing gldA were found to consume at least some of the glycerol added to the media, but in many cases this was not factored into the ethanol yield calculations. This strain produced ethanol at a yield of $94 \%$ of theoretical (Table 1)[52].

A third engineering strategy was overexpression of the bifunctional alcohol and aldehyde dehydrogenase, adhE, which increased ethanol production by 10\% compared with the parent strain (Idh deletion), during growth on xylose. Because the adhE gene was under the control of a xylose-inducible promoter, the effect of adhE expression during growth on glucose was not measured. The resulting strain produced ethanol from xylose at a yield of $95 \%$ of theoretical [24].

\section{Thermoanaerobacter ethanolicus}

Wild type T. ethanolicus JW200 (ATCC 31550) is an anaerobic thermophile similar to both T. mathranii and T. saccharolyticum. A key feature distinguishing T. ethanolicus from T. mathranii is the lack of the ech hydrogenase, which may account for its higher native ethanol yield [53]. T. ethanolicus produces ethanol at $88 \%$ of theoretical yield under certain conditions, although this value has been reported to vary between 55-95\% depending on growth conditions [54]. One engineering strategy used to increase ethanol production in this organism was overexpression of adhE. Transformation of plasmid pTE16 (with adhE cloned into it) into T. ethanolicus resulted in a 3-fold increase in ALDH activity and a 
corresponding $40 \%$ increase in ethanol production (Table 1) [55]. The ethanol and acetate production data reported for this strain only account for 18\% (wild type) and $25 \%$ (adhE overexpression strain) of the glucose carbon initially present, so it is difficult to make any strong conclusions about the effect of this metabolic engineering strategy.

\section{Clostridium thermocellum}

C. thermocellum is an anaerobic thermophile. It is similar to the previously-described

Thermoanaerobacter and Thermoanaerobacterium species in that it produces ethanol, acetate, lactate, $\mathrm{CO}_{2}$ and $\mathrm{H}_{2}$ as its major fermentation products, however it is capable of solubilizing crystalline cellulose (which Thermoanaerobacter and Thermoanaerobacterium cannot) and does not consume pentose sugars (which Thermoanaerobacter and Thermoanaerobacterium do). It is this cellulose-solubilizing ability that has generated interest in metabolic engineering of $\mathrm{C}$. thermocellum for ethanol production.

Initial attempts to engineer $\mathrm{C}$. thermocellum focused on eliminating lactate and acetate production [56]. Elimination of acetate production by deletion of the pta gene had very little effect on ethanol production, although lactate production increased. Development of additional genetic tools allowed the deletion of both Idh and pta simultaneously [57]. Initially there was no increase in ethanol production, but subsequent serial transfer to improve growth resulted in a strain that produced ethanol at $51 \%$ of theoretical yield and a titer of $5.6 \mathrm{~g} / \mathrm{l}$ (Table 1 ). Another approach for engineering $\mathrm{C}$. thermocellum started with a disruption of the sporulation pathway gene spo0A, followed by deletions of Idh and pta and adaptation for rapid growth in a chemostat [37]. The best strain from this strategy produced ethanol at a yield of $29 \%$ of theoretical. It was discovered that the engineered strains were also producing large quantities of amino acids, in some cases $17 \%$ of carbon flux.

Another metabolic engineering strategy involved adapting $C$. thermocellum for growth in the presence of high concentrations of exogenous ethanol [58]. This strain produced less ethanol and more lactate, acetate and ethanol. Subsequent deletion of Idh eliminated lactate production and increased ethanol production. The resulting strain had a yield of $38 \%$ of theoretical (Table 1) [59].

One interesting feature of $\mathrm{C}$. thermocellum is its lack of pyruvate kinase, a common enzyme in glycolysis. C. thermocellum is thought to convert phosphoenolpyruvate to pyruvate via oxaloacetate and malate (known as the 'malate shunt'). To test the hypothesis that this pathway was responsible for low yield, a pyruvate kinase gene from $\mathrm{T}$. saccharolyticum was expressed in $\mathrm{C}$. thermocellum. This did not have a dramatic effect on ethanol production, however subsequent deletion of malic enzyme increased the ethanol yield to $47 \%$ of theoretical (Table 1) [60].

Another metabolic engineering strategy that was attempted was the deletion of hydrogenases. Although $\mathrm{C}$. thermocellum has a several different hydrogenases, many of them can be disabled by deleting a key hydrogenase maturation protein, hydG. Deletion of hydG increased ethanol yield from $34 \%$ to $53 \%$ of theoretical. Further deletion of the ech hydrogenase completely eliminated hydrogen production and further increased the ethanol yield to $61 \%$ of theoretical (Table 1,[29]). 


\section{Caldicellulosiruptor bescii}

C. bescii is an extremely thermophilic anaerobic bacterium with an optimal growth temperature of $75^{\circ} \mathrm{C}$. It consumes both simple and complex polysaccharides (including cellulose) and produces lactate, acetate, carbon dioxide and hydrogen, but does not produce ethanol. To allow for ethanol production, first lactate production was eliminated by deletion of the Idh gene. Then a bifunctional aldehyde and alcohol dehydrogenase, adhE from C. thermocellum, was introduced. The resulting strain produced ethanol at $33 \%$ of the maximum theoretical yield (Table 1) [61]. This strain converts a significant amount of cellobiose to glucose, which suggests that metabolic bottlenecks remain in upper glycolysis.

\section{Pyrococcus furiosus}

P. furiosus is a hyperthermophilic archaeon with an optimum growth temperature of $100^{\circ} \mathrm{C}$. It can consume maltose, cellobiose, beta-glucan, starch and protein. It produces carbon dioxide and hydrogen, but does not produce ethanol. This organism uses the AOR pathway (described above, equations (6) and (7)) for production of acetaldehyde. Recently it was engineered for ethanol production by the expression of adhA from Thermoanaerobacter sp. X514, which allows the acetaldehyde from the AOR pathway to be converted to ethanol [33]. The resulting strain produced ethanol with a yield of $35 \%$ of theoretical (Table 1 ).

\section{Geobacillus thermoglucosidasius}

G. thermoglucosidasius is a thermophilic, facultative-anaerobic bacillus that can ferment glucose, xylose and arabinose and can tolerate up to $10 \%$ ethanol (v/v) [6]. The wild type organism makes predominantly lactate, with small amounts of ethanol, acetate and formate also produced. The first metabolic engineering strategy was elimination of lactate production by deletion of the Idh gene, improving ethanol yield from $22 \%$ to $52 \%$ of theoretical (Table 1) [62]. The next engineering strategy was the deletion of the pyruvate-formate lyase (pfl) gene and overexpression of the pyruvate dehydrogenase ( $p d h$ ) gene. Flux through PFL results in electron transfer to formate. Those electrons can be conserved by formate dehydrogenase (FDH) activity (which is annotated to be present in $\mathrm{G}$. thermoglucosidasius, Figure 1 ). In strains of $\mathrm{G}$. thermoglucosidasius with PFL present, very little formate accumulates (less than $10 \%$ of carbon flux on a C3 basis). Unfortunately, since no pdh deletion has been described in this strain, we cannot say anything about the relative flux distribution between PFL and $\mathrm{PDH}$, only that FDH flux is slightly lower than PFL flux. Of the three changes the Idh deletion and pdh overexpression both substantially increased ethanol production. Deletion of pfl had a mixed effect on ethanol production depending on the strain background. Combining all three modifications (Idh deletion, pfl deletion and pdh overexpression) resulted in strain TM 242 [62]. This strain produced ethanol at a yield of $90 \%$ of theoretical, titer of $15.9 \mathrm{~g} / \mathrm{l}$ and productivity of $2.12 \mathrm{~g} / / \mathrm{h}$ (Table 1 ).

Another strategy for increasing ethanol yield is introducing the PDC pathway (equation 2). A PDC enzyme from Zymomonas mobilis was expressed in $\mathrm{G}$. thermoglucosidasius and found to function at $52^{\circ} \mathrm{C}$, although there was no change in ethanol production [14]. A pdc gene from Gluconobacter oxydans was expressed in the $G$. thermoglucosidasius Idh deletion strain and showed increased ethanol production at $45^{\circ} \mathrm{C}$, but not $52^{\circ} \mathrm{C}$ [15]. The resulting strain, TM 89 pGOF111, produced ethanol at $69 \%$ of 
theoretical yield (Table 1). Overall this strategy was not as successful as the strategy of overexpressing a native pdh gene.

\section{Ogataea polymorpha}

Ogataea (formerly Hansenula) polymorpha is a thermotolerant yeast that can produce ethanol from glucose at $48^{\circ} \mathrm{C}$. Although it has both pyruvate dehydrogenase (PDH) and pyruvate decarboxylase (PDC) enzymes, it seems likely that PDC is the primary pathway for ethanol production for the following reasons. In 0. polymorpha, ethanol production under anaerobic conditions can be improved by overexpression of PDC [63]. In all eukaryotes that do not contain the bifunctional alcohol and aldehyde dehydrogenase gene, adhE (i.e. including 0. polymorpha), ethanol is produced via PDC [64]. Finally, there are no reports of enzymes which can convert acetyl-CoA to acetaldehyde in yeast [65].

Another metabolic engineering strategy involved overexpression of gamma glutamylcysteine synthetase, which is thought to help the cell tolerate ethanol stress. The resulting strain, DL-1 356 mcHpGSH2, was able to produce ethanol with a yield of $96 \%$ of theoretical, titer up to $45 \mathrm{~g} / \mathrm{l}$ and productivity of $1 \mathrm{~g} / \mathrm{l} / \mathrm{h}$ (Table 1 ) [66].

\section{Improving ethanol titer}

As reviewed elsewhere [4], growth of thermophilic saccharolytic bacteria not previously exposed to ethanol is generally inhibited by modest (e.g. $\leq 20 \mathrm{~g} / \mathrm{L}$ ) concentrations of added ethanol. Growth in the presence of ethanol added at concentrations $\geq 50 \mathrm{~g} / \mathrm{L}$ has been demonstrated for many organisms in this category following selection in the presence of ethanol. Maximum concentrations of ethanol produced by thermophilic bacteria are in general lower - typically by a factor of two or more - than the maximum concentrations of added ethanol that permit growth. We have previously termed this phenomenon the "titer gap" [5]. Economical recovery of ethanol requires concentrations of $>40 \mathrm{~g} / \mathrm{l}$ [67]. Thus it appears that production of ethanol at these concentrations is not limited per se by tolerance, but some other factor.

Closing the titer gap in order to produce commercially recoverable ethanol concentrations will likely require understanding the mechanisms of ethanol inhibition and taking steps to ameliorate them. Results reported to date point to imbalances in the concentrations of reduced and oxidized nicotinamide cofactors as being particularly important factors leading to the cessation of growth and fermentation due to ethanol. In both $\mathrm{C}$. thermocellum and T. pseudethanolicus, it has been shown that mutations which reduce NADH-linked alcohol dehydrogenase activity are associated with increased ethanol tolerance $[27,68]$. For T. pseudethanolicus, it has been suggested that elevated levels of NADH in the presence of ethanol inhibit glycolysis at the glyceraldehyde-3-phosphate dehydrogenase (GAPDH) step [69]. In 0. polymorpha, ethanol titer was improved from 13 to $45 \mathrm{~g} / \mathrm{I}$ by overexpression of the GSH1 gene to increase intracellular levels of glutathione (Table 1) [66]. Glutathione is a major cellular redox buffer, so modulating glutathione levels to increase ethanol production suggests that ethanol was causing a redox imbalance.

Exposure to ethanol has been correlated with changes in membrane composition in both $\mathrm{C}$. thermocellum [70] and T. ethanolicus [68], and it has been suggested that these changes compensate for 
changes in membrane fluidity due to the presence of ethanol. Commenting on ethanol tolerance of $\mathrm{T}$. pseudethanolicus, Lovitt et al. [69] suggest that inhibition by moderate ethanol concentrations (e.g. 4 \%) can be rectified by changes in redox metabolism, but that cell membrane properties are responsible for tolerance and inhibition at $8 \%$ ethanol. In our view, redox imbalances are a more likely explanation than membrane effects for the titer gap exhibited by thermophiles in studies to date, but membrane effects may become important as redox imbalances are rectified.

Producing high concentrations of ethanol requires that high concentrations of substrate be fermented. Cessation of growth and/or fermentation at high substrate concentrations can occur for many reasons, and care must be taken to avoid mistakenly attributing such cessation to ethanol. Working with continuous cultures of T. thermosaccharolyticum, Baskaran et al. [47] attributed cessation of growth and fermentation at feed xylose concentrations exceeding $70 \mathrm{~g} / \mathrm{L}$ to salt resulting from neutralizing organic acid production rather than to ethanol. Similarly, inhibition of T. saccharolyticum grown at high substrate concentrations was attributed to salt accumulation due to neutralization of acid produced in conjunction with ammonia uptake. Salt inhibition was avoided by introduction of the urease operon, resulting in the maximum ethanol titer increasing from 25 to $50 \mathrm{~g} / \mathrm{L}$ [48]. The urea-utilizing strain of $\mathrm{T}$. saccharolyticum was subsequently shown to produce ethanol at $64 \mathrm{~g} / \mathrm{L}$ [49], believed to be the highest level reported for a thermophilic bacterium to date and sufficient for industrial application $[4,67]$.

\section{Improving understanding of metabolic pathways}

Knowledge of metabolic network stoichiometry is required for the rational metabolic engineering. Genome analysis and automated annotation can provide a basic framework of metabolism. Functional genomics (proteomics, transcriptomics) can complement and refine our interpretation by allowing us to observe which metabolic pathways are at play under different growth conditions in both wild type and mutant strains $[71,72]$. However direct biochemical assay remains the gold standard for deepening our understanding of metabolism, particularly for subtle effects such as cofactor preference. For example, the importance of GTP as an important energy currency in C. thermocellum has been recently described thanks to the observation that its glucokinase is GTP rather that ATP-dependent [73]. Another example is the discovery of the widespread role of flavin-based electron bifurcation in microbial metabolism [34].

In addition to studying a metabolic pathway in the context of its native host, pathways can be studied by transfer to an exogenous host. Attempts to transfer a pathway often result in the discovery of a previously-overlooked component. For example, transferring the pdc gene from Z. mobilis to E. coli resulted in modest ethanol production which revealed the necessity of additionally transferring the $Z$. mobilis adhB gene [74]. To truly understand a pathway it is often necessary to transfer into several different exogenous hosts.

\section{Conclusion}

To allow for inexpensive production of ethanol, an organism needs to achieve a yield of $>90 \%$ of theoretical, titer of $>40 \mathrm{~g} / \mathrm{l}$ and productivity of $>1 \mathrm{~g} / \mathrm{l} / \mathrm{h}$ [67]. There are many examples of metabolic 
engineering for increased yield, and it is possible to observe some similarities among approaches. Titer and productivity have only begun to be studied, and our understanding of the factors underlying these properties is still piecemeal.

Of the four elementary modes for ethanol production from pyruvate, we have found thermophilic examples for three of them: the PDH mode from $G$. thermoglucosidasius, the PFOR mode from T. saccharolyticum (and several others) and the PDC mode from 0. polymorpha. In most of the cases presented, a native pathway has been modified to allow ethanol production near theoretical maximum yield. In C. bescii and P. furiosus, ethanol was not produced in the wild type strains (or produced at trace levels), and addition of an exogenous gene dramatically increased ethanol production, however in both of these strains the ethanol yield is far below the theoretical maximum.

There are no examples of transferring a high-yielding thermophilic ethanol production pathway to a strain with low ethanol production that result in ethanol production at near theoretical yield. By contrast, the mesophilic pET operon, consisting of pyruvate decarboxylase and alcohol dehydrogenase from Z mobilis, reliably produces ethanol at high yield in a wide range of mesophilic organisms [75-77]. It is hoped that by better understanding the genes and pathways involved in the thermophilic ethanol production pathways, we will one day be able to transfer these pathways to new organisms as readily as the pET pathway in mesophiles.

\section{Acknowledgements}

We wish to thank Johannes $P$. van Dijken for many useful discussions.

Funds provided to RS by Genome Canada for the project "M icrobial Genomics for Biofuels and CoProducts from Biorefining Processes" $\left(\mathrm{MGCB}^{2}\right)$. Funds provided to DO and LL by the BioEnergy Science center.

The BioEnergy Science Center is a U.S. Department of Energy Bioenergy Research Center supported by the Office of Biological and Environmental Research in the DOE Office of Science.

\section{Works cited}

1. Dale BE, Anderson JE, Brown RC, Csonka S, Dale VH, Herwick G, Jackson RD, Jordan N, Kaffka S, Kline KL, et al.: Take a Closer Look: Biofuels Can Support Environmental, Economic and Social Goals. Environ. Sci. Technol. 2014, 48:7200-7203.

2. Singer S, Denruyter J-P, Jeffries B: The Energy Report 100\% Renewable Energy by 2050. 2011.

3. OECD-FAO Agricultural Outlook 2014. OECD Publishing; 2014.

4. Lynd LR, Weimer PJ, van ZyI WH, Pretorius IS: Microbial cellulose utilization: fundamentals and biotechnology. Microbiol. Mol. Biol. Rev. 2002, 66:506. 
5. Olson DG, M CBride JE, Shaw AJ, Lynd LR: Recent progress in consolidated bioprocessing. Curr. Opin. Biotechnol. 2012, 23:396-405.

6. Barnard D, Casanueva A, Tuffin M, Cowan D: Extremophiles in biofuel synthesis. Environ. Technol. 2010, 31:871-888.

7. Chang T, Yao S: Thermophilic, lignocellulolytic bacteria for ethanol production: current state and perspectives. Appl. Microbiol. Biotechnol. 2011, 92:13-27.

8. Lin $L, X u J$ : Dissecting and engineering metabolic and regulatory networks of thermophilic bacteria for biofuel production. Biotechnol. Adv. 2013, 31:827-37.

9. Taylor M P, Eley KL, M artin S, Tuffin MI, Burton SG, Cowan DA: Thermophilic ethanologenesis: future prospects for second-generation bioethanol production. Trends Biotechnol. 2009, 27:398-405.

10. Carere CR, Rydzak T, Verbeke TJ, Cicek N, Levin DB, Sparling R: Linking genome content to biofuel production yields: a meta-analysis of major catabolic pathways among select $\mathrm{H} 2$ and ethanol-producing bacteria. BM C M icrobiol. 2012, 12:295.

** Comprehensive review of the fermentation pathways of mixed-acid fermenting bacteria

11. Izquierdo JA, Sizova M V, Lynd LR: Diversity of bacteria and glycosyl hydrolase family $\mathbf{4 8}$ genes in cellulolytic consortia enriched from thermophilic biocompost. Appl. Environ. M icrobiol. 2010, 76:3545-53.

12. Sahm H, Bringer-M eyer S, Schimz K-L: Pyruvate decarboxylase from Zymomonas mobilis. Isolation and partial characterization. Arch. Microbiol. 1986, 146:105-110.

13. Raj KC, Talarico LA, Ingram LO, M aupin-Furlow JA: Cloning and Characterization of the Zymobacter palmae Pyruvate Decarboxylase Gene (pdc) and Comparison to Bacterial Homologues. 2002, 68:2869-2876.

14. Thompson A, Studholme D, Green E, Leak D: Heterologous expression of pyruvate decarboxylase in Geobacillus thermoglucosidasius. Biotechnol. Lett. 2008, 30:1359-1365.

15. Van Zyl LJ, Taylor M P, Eley K, Tuffin M, Cowan DA: Engineering pyruvate decarboxylasemediated ethanol production in the thermophilic host Geobacillus thermoglucosidasius. Appl. Microbiol. Biotechnol. 2013, doi:10.1007/s00253-013-5380-1.

16. Ma K, Hutchins A, Sung SJS, Adams M WW: Pyruvate ferredoxin oxidoreductase from the hyperthermophilic archaeon, Pyrococcus furiosus, functions as a CoA-dependent pyruvate decarboxylase. Proc. Natl. Acad. Sci. U. S. A. 1997, 94:9608-9613.

17. Eram MS, Oduaran E, Ma K: The Bifunctional Pyruvate Decarboxylase/Pyruvate Ferredoxin Oxidoreductase from Thermococcus guaymasensis. Archaea 2014, 2014:349379. 
18. Berríos-Rivera S: Metabolic Engineering of Escherichia coli: Increase of NADH Availability by Overexpressing an NAD+-Dependent Formate Dehydrogenase. M etab. Eng. 2002, 4:217-229.

19. Biegel E, M üller V: A Na+-translocating pyrophosphatase in the acetogenic bacterium Acetobacterium woodii. J. Biol. Chem. 2011, 286:6080-4.

20. Schut GJ, Bridger SL, Adams M WW: Insights into the metabolism of elemental sulfur by the hyperthermophilic archaeon Pyrococcus furiosus: characterization of a coenzyme A- dependent NAD(P)H sulfur oxidoreductase. J. Bacteriol. 2007, 189:4431-41.

21. Wang $\mathrm{S}$, Huang $\mathrm{H}, \mathrm{M}$ oll $\mathrm{J}$, Thauer RK: NADP reduction with reduced ferredoxin and NADP reduction with NADH are coupled via an electron-bifurcating enzyme complex in Clostridium kluyveri.

J. Bacteriol. 2010, 192:5115-23.

* The first report of a hitherto unknown enzymatic activity that increases the diversity of redox reactions in anaerobes

22. Carere CR, Rydzak T, Cicek N, Levin DB, Sparling R: Role of transcription and enzyme activities in redistribution of carbon and electron flux in response to N2 and $\mathrm{H} 2$ sparging of open-batch cultures of Clostridium thermocellum ATCC 27405. Appl. M icrobiol. Biotechnol. 2014, doi:10.1007/s00253-013-5500-y.

23. Shaw AJ, Jenney Jr FE, Adams MWW, Lynd LR: End-product pathways in the xylose fermenting bacterium, Thermoanaerobacterium saccharolyticum. Enzyme M icrob. Technol. 2008, 42:453458.

24. Yao S, M ikkelsen MJ: Identification and Overexpression of a Bifunctional Aldehyde/Alcohol Dehydrogenase Responsible for Ethanol Production in Thermoanaerobacter mathranii. J. M ol. Microbiol. Biotechnol. 2010, 19:123-133.

25. Bhandiwad A, Guseva A, Lynd L: Metabolic Engineering of Thermoanaerobacterium thermosaccharolyticum for Increased n-Butanol Production. Adv. M icrobiol. 2013, 2013:46-51.

26. Lo J, Zheng T, Hon S, Olson D, Lynd L: The bifunctional alcohol and aldehyde dehydrogenase gene, adhe, is necessary for ethanol production in Clostridium thermocellum and Thermoanaerobacterium saccharolyticum. J. Bacteriol. 2015, (in press).

27. Brown SD, Guss AM, Karpinets T V, Parks JM, Smolin N, Yang SH, Land M L, Klingeman DM, Bhandiwad $A$, Rodriguez $M$, et al.: Mutant alcohol dehydrogenase leads to improved ethanol tolerance in Clostridium thermocellum. Proc. Natl. Acad. Sci. U. S. A. 2011, 108:13752-7.

* The observation that a point mutation in a metabolic enzyme can increase ethanol tolerance suggests that ethanol inhibition of wild-type strain may be metabolic rather than biophysical (e.g. loss of membrane integrity) 
28. Shao XJ, Raman B, Zhu MJ, M ielenz JR, Brown SD, Guss AM, Lynd LR: Mutant selection and phenotypic and genetic characterization of ethanol-tolerant strains of Clostridium thermocellum. Appl. M icrobiol. Biotechnol. 2011, 92:641-652.

* Demonstrates that $C$. thermocellum can be transferred on cellulose in the presence of $50 \mathrm{~g} / \mathrm{l}$ ethanol

29. Biswas R, Zheng T, Olson DG, Lynd LR, Guss AM : Elimination of hydrogenase active site assembly blocks $\mathrm{H} 2$ production and increases ethanol yield in Clostridium thermocellum. Biotechnol. Biofuels 2015, (in press).

30. Extance J, Crennell SJ, Eley K, Cripps R, Hough DW, Danson MJ: Structure of a bifunctional alcohol dehydrogenase involved in bioethanol generation in Geobacillus thermoglucosidasius. Acta Crystallogr. D. Biol. Crystallogr. 2013, 69:2104-15.

31. White H, Strobl G, Feicht R, Simon H: Carboxylic acid reductase: a new tungsten enzyme catalyses the reduction of non-activated carboxylic acids to aldehydes. Eur. J. Biochem. 1989, 184:89-96.

32. Kopke M, Held C, Hujer S, Liesegang H, Wiezer A, Wollherr A, Ehrenreich A, Liebl W, Gottschalk G, Durre P: Clostridium ljungdahlii represents a microbial production platform based on syngas. Proc. Natl. Acad. Sci. 2010, 107:13087-13092.

33. Basen M, Schut GJ, Nguyen DM, Lipscomb GL, Benn RA, Prybol C), Vaccaro BJ, Poole FL, Kelly RM, Adams MWW: Single gene insertion drives bioalcohol production by a thermophilic archaeon. Proc. Natl. Acad. Sci. 2014, doi:10.1073/pnas.1413789111.

* Conclusive evidence of aldehyde-ferredoxin oxidoreductase pathway for ethanol production.

34. Buckel W, Thauer RK: Energy conservation via electron bifurcating ferredoxin reduction and proton/Na(+) translocating ferredoxin oxidation. Biochim. Biophys. Acta 2013, 1827:94-113.

** Energy conservation via electron bifurcation is a critical concept in fermentative metabolism. This paper review the recent advances in our understanding of this phenomenon.

35. Schäfer T, Xavier K, Santos H, Schönheit P: Glucose fermentation to acetate and alanine in resting cell suspensions of Pyrococcus furiosus: Proposal of a novel glycolytic pathway based on 13C labeling data and enzyme activities. FEM S M icrobiol. Lett. 1994, 121:107-114.

36. Ravot G, Ollivier B, Fardeau ML, Patel BK, Andrews KT: L-alanine production from glucose fermentation by hyperthermophilic members of the domains bacteria and Archaea : a remnant of an ancestral metabolism ?. Appl. Environ. M icrobiol. 1996, 62:2657-2659.

37. Van der Veen D, Lo J, Brown SD, Johnson CM, Tschaplinski TJ, Martin M, Engle NL, van den Berg RA, Argyros AD, Caiazza NC, et al.: Characterization of Clostridium thermocellum strains with disrupted fermentation end-product pathways. J. Ind. M icrobiol. Biotechnol. 2013, 40:725-34. 
38. Taylor M P, van Zyl L, Tuffin IM, Leak DJ, Cowan DA: Genetic tool development underpins recent advances in thermophilic whole-cell biocatalysts. Microb. Biotechnol. 2011, 4:438-48.

39. Chung D-H, Huddleston JR, Farkas J, Westpheling J: Identification and characterization of Cbel, a novel thermostable restriction enzyme from Caldicellulosiruptor bescii DSM 6725 and a member of a new subfamily of Haelli-like enzymes. J. Ind. M icrobiol. Biotechnol. 2011, 38:186777.

40. Chung D, Farkas J, Huddleston JR, Olivar E, Westpheling J: Methylation by a unique $\boldsymbol{\alpha}$-class N4cytosine methyltransferase is required for DNA transformation of Caldicellulosiruptor bescii DSM6725. PLoS One 2012, 7:e43844.

41. Lipscomb GL, Stirrett K, Schut GJ, Yang F, Jenney FE, Scott RA, Adams M WW, Westpheling J: Natural competence in the hyperthermophilic archaeon Pyrococcus furiosus facilitates genetic manipulation: construction of markerless deletions of genes encoding the two cytoplasmic hydrogenases. Appl. Environ. M icrobiol. 2011, 77:2232-8.

42. Faber K, Haima P, Harder W, Veenhuis M, Geert A: Highly-efficient electrotransformation of the yeast Hansenula polymorpha. Curr. Genet. 1994, 16:305-310.

43. Liu SY, Gherardini FC, M atuschek M, Bahl H, Wiegel J: Cloning, sequencing, and expression of the gene encoding a large S-layer-associated endoxylanase from Thermoanaerobacterium sp. strain JW/SL-YS 485 in Escherichia coli. J. Bacteriol. 1996, 178:1539-47.

44. Desai SG, Guerinot ML, Lynd LR: Cloning of L-lactate dehydrogenase and elimination of lactic acid production via gene knockout in Thermoanaerobacterium saccharolyticum JW/SL-YS485. Appl. M icrobiol. Biotechnol. 2004, 65:600-5.

45. Shaw AJ, Podkaminer KK, Desai SG, Bardsley JS, Rogers SR, Thorne PG, Hogsett DA, Lynd LR: Metabolic engineering of a thermophilic bacterium to produce ethanol at high yield. Proc. Natl. Acad. Sci. U. S. A. 2008, 105:13769-74.

* First demonstration of high ethanol yield in an organism thought to metabolize pyruvate via pyruvate ferredoxin oxidoreductase

46. Shaw AJ, Covalla SF, Hogsett DA, Herring CD: Marker Removal System for Thermoanaerobacterium saccharolyticum and Development of a Markerless Ethanologen. Appl. Environ. Microbiol. 2011, 77:2534-2536.

** Example of engineering the pyruvate-ferredoxin oxidoreductase mode for ethanol production at high yield and titer

47. Lynd LR, Baskaran S, Casten S: Salt Accumulation Resulting from Base Added for pH Control, and Not Ethanol, Limits Growth of Thermoanaerobacterium thermosaccharolyticum HG-8 at Elevated Feed Xylose Concentrations in Continuous Culture. Biotechnol. Prog. 2001, 17:118125. 
48. Shaw AJ, Covalla SF, M iller BB, Firliet BT, Hogsett DA, Herring CD: Urease expression in a Thermoanaerobacterium saccharolyticum ethanologen allows high titer ethanol production. M etab. Eng. 2012, 14:528-32.

49. Herring CD, Kenealy WR, Shaw AJ, Raman B, Tschaplinski TJ, Brown SD, Davison BH, Covalla SF, Sillers WR, Xu H, et al.: Final Report on Development of Thermoanaerobacterium saccharolyticum for the conversion of lignocellulose to ethanol. United States Dep. Energy 2012, doi:10.2172/1033560.

50. Shaw AJ, Hogsett DA, Lynd LR: Identification of the [FeFe]-hydrogenase responsible for hydrogen generation in Thermoanaerobacterium saccharolyticum and demonstration of increased ethanol yield via hydrogenase knockout. J. Bacteriol. 2009, 191:6457-64.

51. Georgieva TI, M ikkelsen MJ, Ahring BK: Ethanol production from wet-exploded wheat straw hydrolysate by thermophilic anaerobic bacterium Thermoanaerobacter BG1L1 in a continuous immobilized reactor. Appl. Biochem. Biotechnol. 2008, 145:99-110.

52. Yao S, M ikkelsen MJ: Metabolic engineering to improve ethanol production in Thermoanaerobacter mathranii. Appl. Microbiol. Biotechnol. 2010, 88:199-208.

53. Verbeke TJ, Zhang X, Henrissat B, Spicer V, Rydzak T, Krokhin O V, Fristensky B, Levin DB, Sparling $\mathrm{R}$ : Genomic evaluation of Thermoanaerobacter spp. for the construction of designer co-cultures to improve lignocellulosic biofuel production. PLOS One 2013, 8:e59362.

54. Wiegel J, Ljungdahl L: Thermoanaerobacter ethanolicus gen. nov., spec. nov., a new, extreme thermophilic, anaerobic bacterium. Arch. M icrobiol. 1981, 1979:343-348.

55. Peng $\mathrm{H}, \mathrm{Wu} \mathrm{G}$, Shao W: The aldehyde/alcohol dehydrogenase (AdhE) in relation to the ethanol formation in Thermoanaerobacter ethanolicus JW200. Anaerobe 2008, 14:125-127.

56. Tripathi SA, Olson DG, Argyros DA, M iller BB, Barrett TF, M urphy DM, M cCool JD, Warner AK, Rajgarhia VB, Lynd LR, et al.: Development of pyrF-based genetic system for targeted gene deletion in Clostridium thermocellum and creation of a pta mutant. Appl. Environ. M icrobiol. 2010, 76:6591-6599.

57. Argyros DA, Tripathi SA, Barrett TF, Rogers SR, Feinberg LF, Olson DG, Foden JM, Miller BB, Lynd $L R$, Hogsett $D A$, et al.: High ethanol titers from cellulose by using metabolically engineered thermophilic, anaerobic microbes. Appl. Environ. M icrobiol. 2011, 77:8288-94.

58. Rydzak T, Levin DB, Cicek N, Sparling R: End-product induced metabolic shifts in Clostridium thermocellum ATCC 27405. Appl. M icrobiol. Biotechnol. 2011, 92:199-209.

59. Biswas R, Prabhu S, Lynd LR, Guss AM : Increase in Ethanol Yield via Elimination of Lactate Production in an Ethanol-Tolerant Mutant of Clostridium thermocellum. PLoS One 2014, 9:e86389. 
60. Deng Y, Olson DG, Zhou J, Herring CD, Joe Shaw A, Lynd LR: Redirecting carbon flux through exogenous pyruvate kinase to achieve high ethanol yields in Clostridium thermocellum. M etab. Eng. 2013, 15:151-8.

61. Chung D, Cha M, Guss AM, Westpheling J: Direct conversion of plant biomass to ethanol by engineered Caldicellulosiruptor bescii. Proc. Natl. Acad. Sci. U. S. A. 2014, 111:8931-6.

* Expression of the adhE gene from Clostridium thermocellum allowed ethanol production in Caldicellulosiruptor bescii, which previously had not been shown to produce ethanol. Ethanol is produced at high yield, although substrate consumption is low.

62. Cripps RE, Eley K, Leak DJ, Rudd B, Taylor M, Todd M, Boakes S, M artin S, Atkinson T: Metabolic engineering of Geobacillus thermoglucosidasius for high yield ethanol production. M etab. Eng. 2009, 11:398-408.

** Example of engineering the pyruvate dehydrogenase mode for ethanol production at high yield and titer

63. Ishchuk OP, Voronovsky AY, Stasyk O V, Gayda GZ, Gonchar M V, Abbas CA, Sibirny AA: Overexpression of pyruvate decarboxylase in the yeast Hansenula polymorpha results in increased ethanol yield in high-temperature fermentation of xylose. FEM S Yeast Res. 2008, 8:1164-74.

64. Atteia A, van Lis R, Tielens AGM, M artin WF: Anaerobic energy metabolism in unicellular photosynthetic eukaryotes. Biochim. Biophys. Acta 2013, 1827:210-23.

65. Pronk JT, Steensma HY, van Dijken JP: Pyruvate metabolism in Saccharomyces cerevisiae. Yeast 1996, 12:1607-1633.

66. Grabek-Lejko D, Kurylenko 00, Sibirny VA, Ubiyvovk VM, Penninckx M, Sibirny AA: Alcoholic fermentation by wild-type Hansenula polymorpha and Saccharomyces cerevisiae versus recombinant strains with an elevated level of intracellular glutathione. J. Ind. Microbiol. Biotechnol. 2011, 38:1853-9.

** Example of engineering the pyruvate decarboxylase mode for ethanol production at high yield and titer

67. Dien BS, Cotta M A, Jeffries TW: Bacteria engineered for fuel ethanol production: current status. Appl. M icrobiol. Biotechnol. 2003, 63:258-266.

68. Burdette DS, Jung S, Shen G, Hollingsworth RI, Zeikus JG: Physiological Function of Alcohol Dehydrogenases and Long-Chain (C 30) Fatty Acids in Alcohol Tolerance of Thermoanaerobacter ethanolicus. 2002, 68:1914-1918. 
69. Lovitt RW, Shen GJ, Zeikus JG: Ethanol Production by Thermophilic Bacteria: Biochemical Basis for Ethanol and Hydrogen Tolerance in Clostridium thermohydrosulfuricum. J. Bacteriol. 1988, 170:2809-2815.

70. Herrero AA, Gomez RF: Development of ethanol tolerance in Clostridium thermocellum: Effect of growth temperature. Appl. Environ. Microbiol. 1980, 40:571-577.

71. Lin L, Song H, Tu Q, Qin Y, Zhou A, Liu W, He Z, Zhou J, Xu J: The Thermoanaerobacter glycobiome reveals mechanisms of pentose and hexose co-utilization in bacteria. PLOS Genet. 2011, 7:e1002318.

72. Schut GJ, Brehm SD, Datta S, Adams MWW: Whole-Genome DNA Microarray Analysis of a Hyperthermophile and an Archaeon : Pyrococcus furiosus Grown on Carbohydrates or Peptides. J. Bacteriol. 2003, 185:3935-3947.

73. Zhou J, Olson DG, Argyros DA, Deng Y, van Gulik W M, van Dijken JP, Lynd LR: Atypical glycolysis in Clostridium thermocellum. Appl. Environ. M icrobiol. 2013, 79:3000-8.

* Reveals many differences from the glycolysis pathway normally assumed.

74. Stephanopoulos GN, Aristidou AA, Nielsen J: M etabolic Engineering: Principles and M ethodologies. Academic Press; 1998.

75. Ingram LO, Conway T, Clark DP, Sewell GW, Preston JF: Genetic engineering of ethanol production in Escherichia coli. Appl. Environ. Microbiol. 1987, 53:2420-2425.

76. Enquist-Newman M, Faust AM E, Bravo DD, Santos CNS, Raisner RM, Hanel A, Sarvabhowman P, Le $C$, Regitsky DD, Cooper SR, et al.: Efficient ethanol production from brown macroalgae sugars by a synthetic yeast platform. Nature 2014, 505:239-43.

77. Guedon E, Petitdemange H, Poincare H, Desvaux M : Improvement of cellulolytic properties of Clostridium cellulolyticum by metabolic engineering. Appl. Environ. M icrobiol. 2002, 68:53-58. 
Thermophilic ethanol production pathways

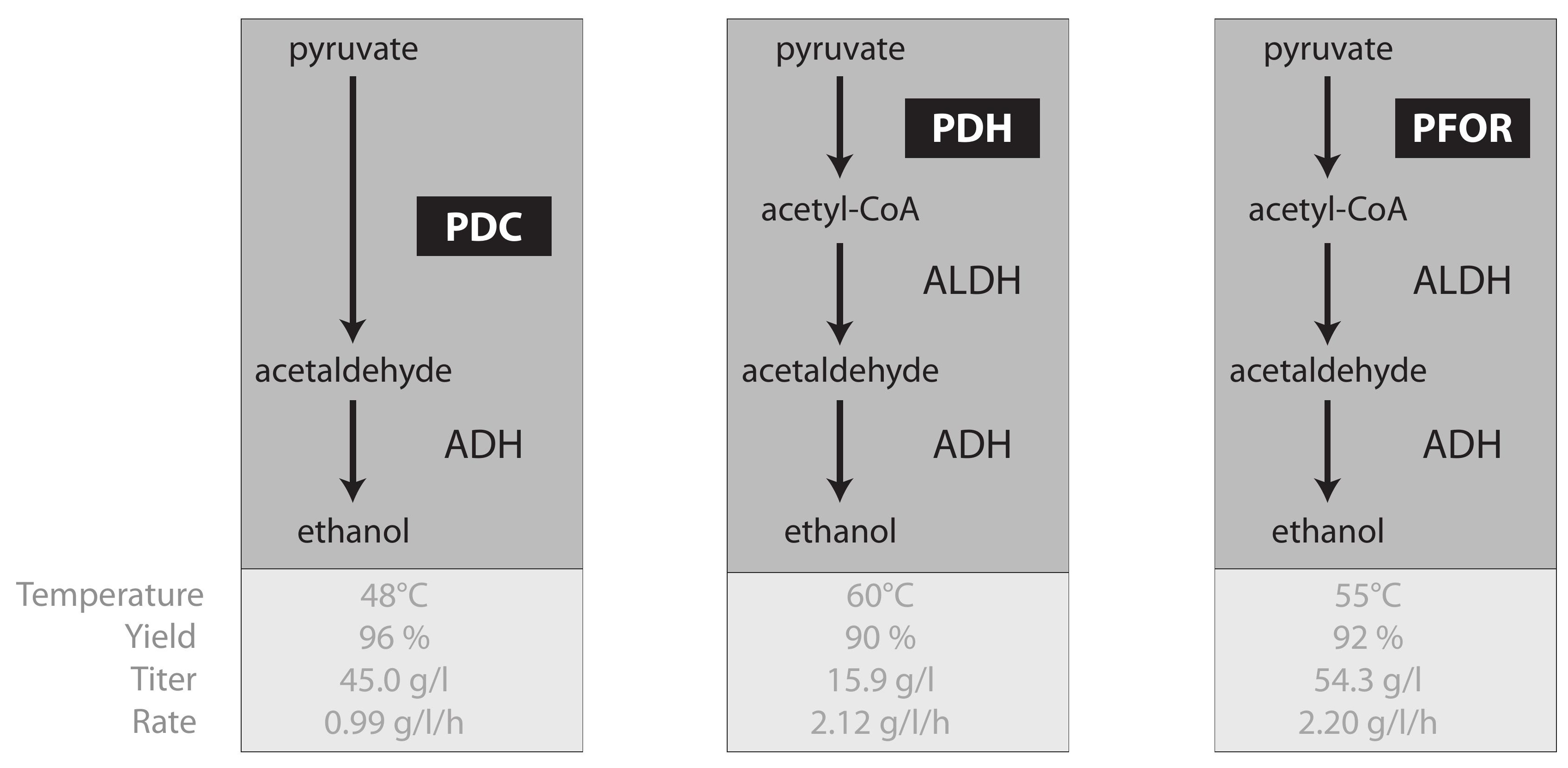




\section{Making Sense of Biodiversity: $\mathrm{H}_{2}$ /EtOH Producing Capabilities}

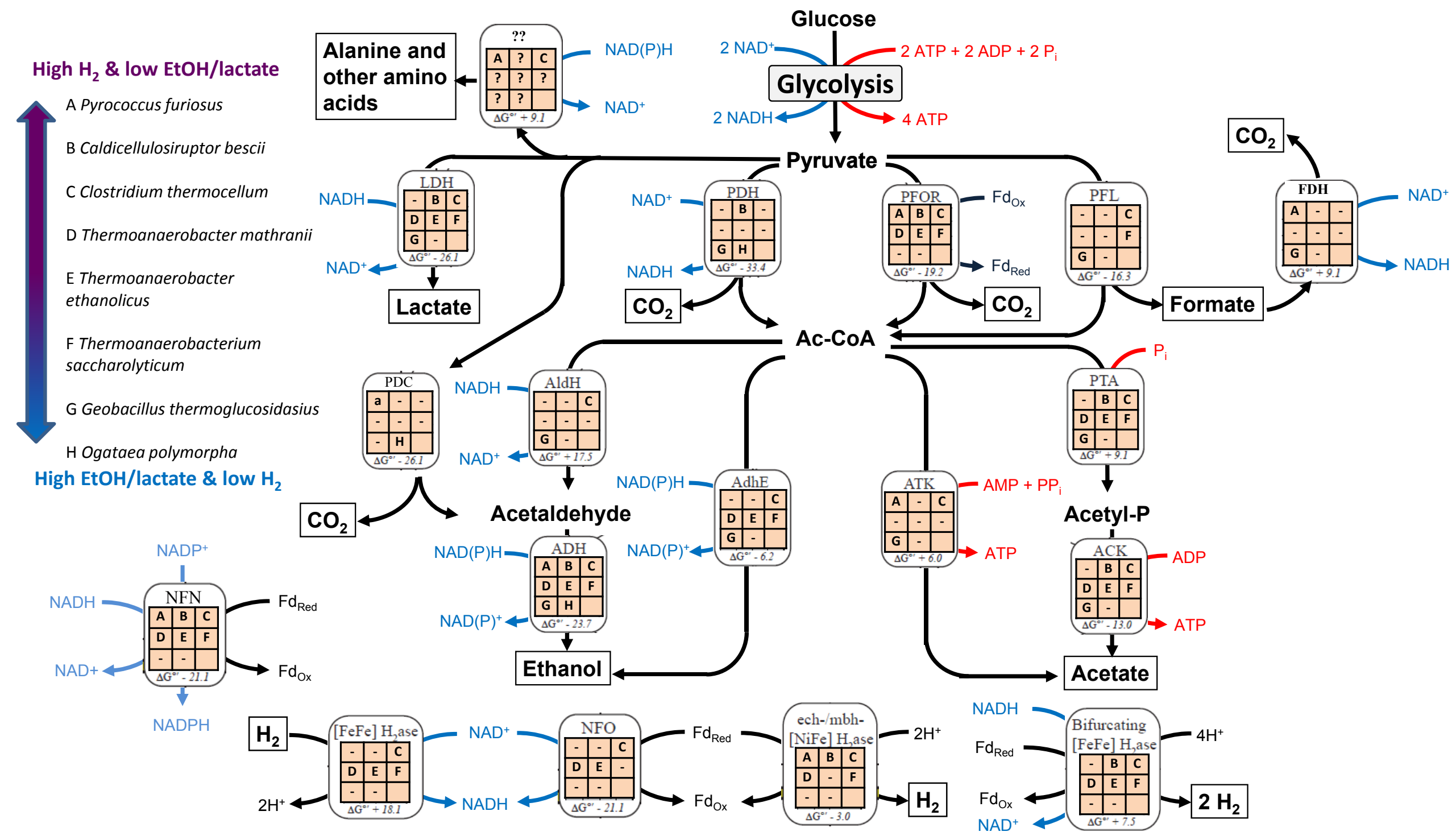




\begin{tabular}{|c|c|c|c|c|c|c|c|c|}
\hline Organism & Strain & Description & Yield & Titer & Productivity & Temperature & Reference & Notes \\
\hline poc mode & & & $\begin{array}{l}\text { Sotheretica } \\
\text { maximum }\end{array}$ & $g / 1$ & $g / / / h$ & $c$ & & \\
\hline 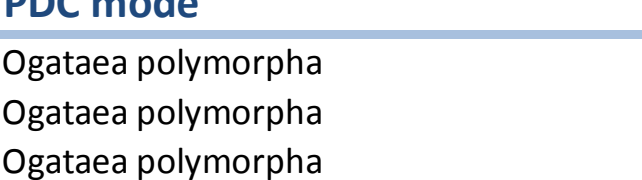 & 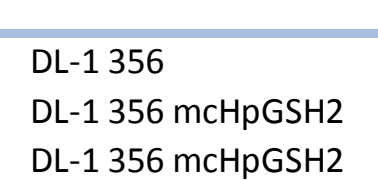 & 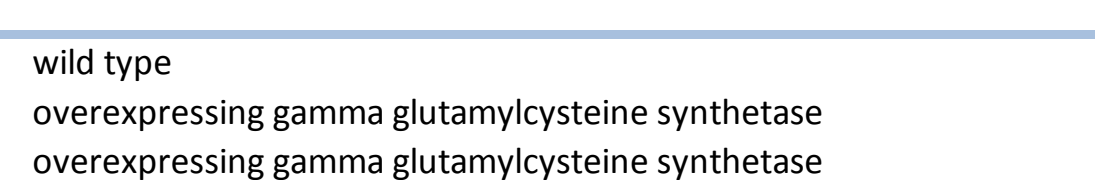 & 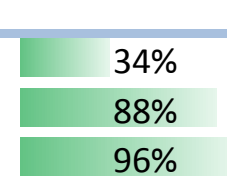 & 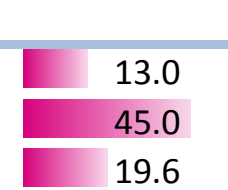 & 099 & 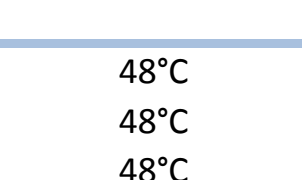 & 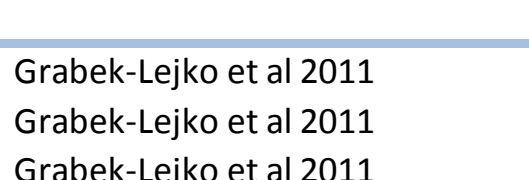 & 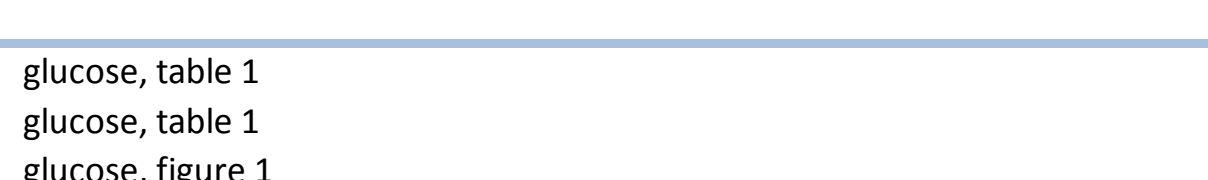 \\
\hline 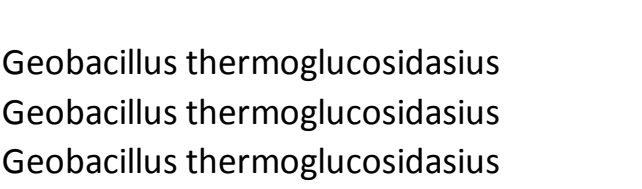 & 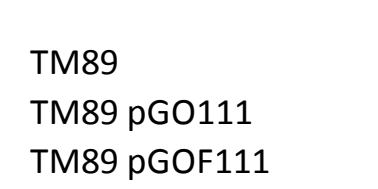 & 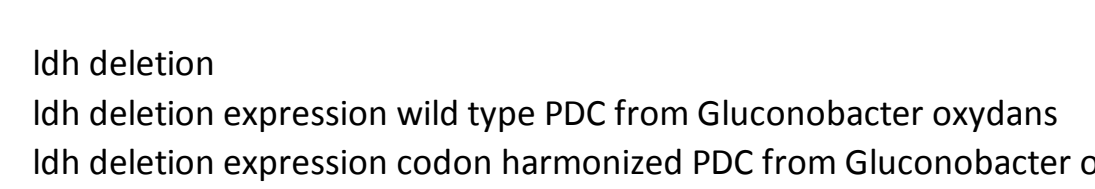 & 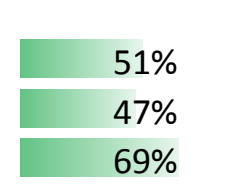 & & & $\begin{array}{l}45^{\circ} \mathrm{C} \\
45^{4} \mathrm{C} \\
45^{\circ} \mathrm{C}\end{array}$ & 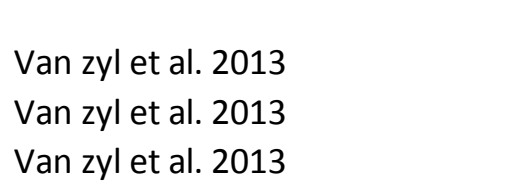 & 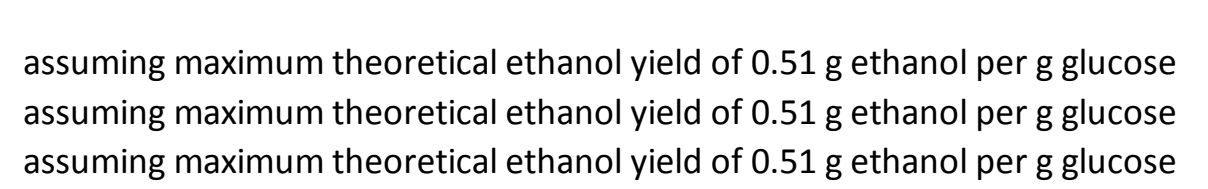 \\
\hline POH mode & & & & & & & & \\
\hline 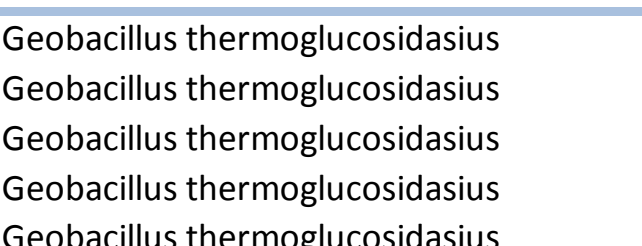 & 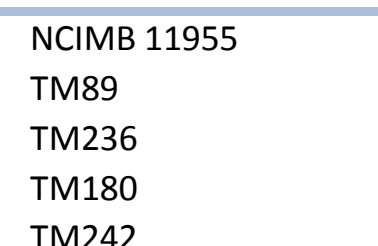 & 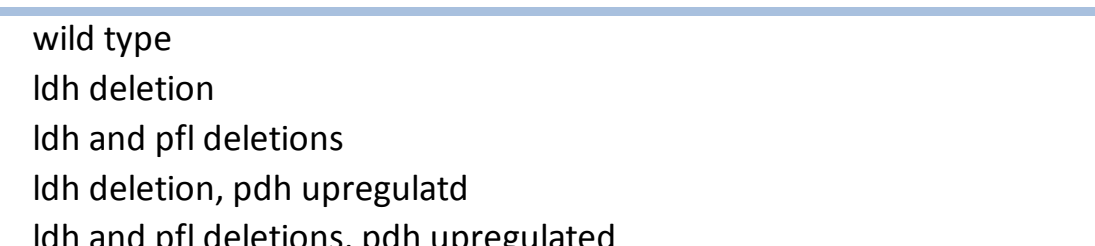 & 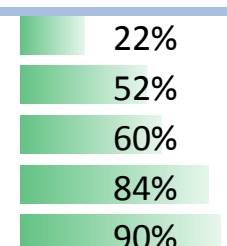 & 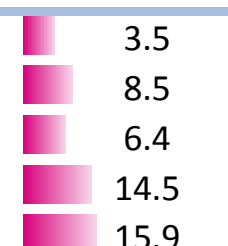 & $\begin{array}{l}0.54 \\
0.70 \\
0.86 \\
2.23 \\
2.3\end{array}$ & 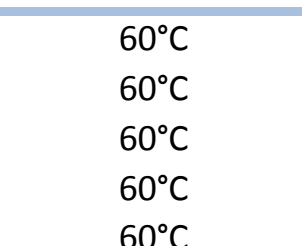 & 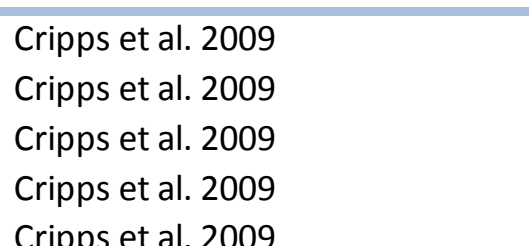 & 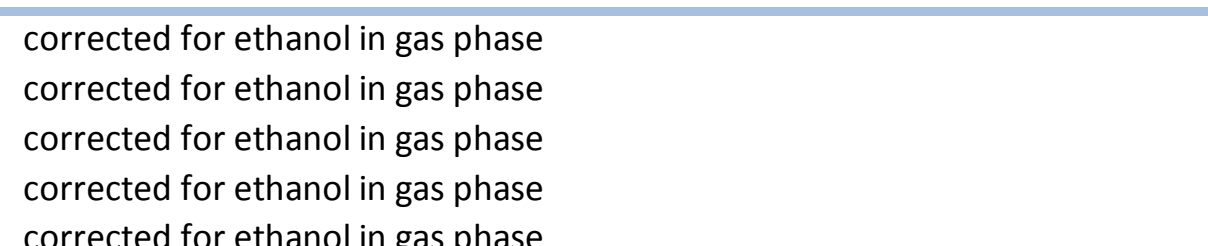 \\
\hline PFOR mode & & & & & & & & \\
\hline 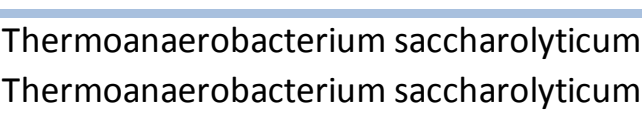 & $\underset{\text { TD1 }}{\mathrm{wt}}$ & $\begin{array}{l}\text { Wild thpe } \\
\text { duh deletion }\end{array}$ & $60 \%$ & $\begin{array}{l}1.7 \\
1.8\end{array}$ & $=\begin{array}{l}0.29 \\
0.32\end{array}$ & $\begin{array}{l}50^{\circ} \mathrm{c} \\
\text { soc }^{\circ}\end{array}$ & 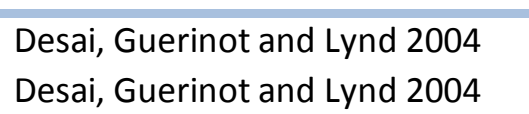 & 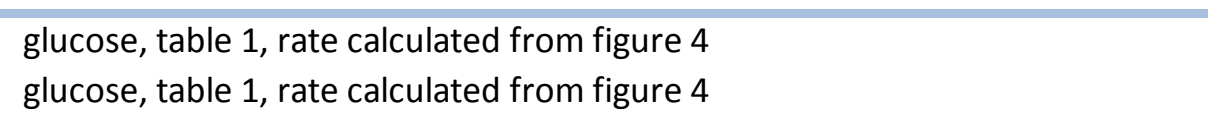 \\
\hline 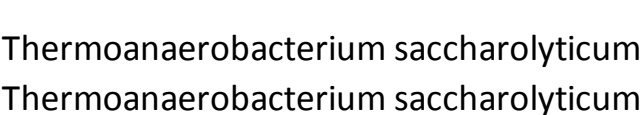 & 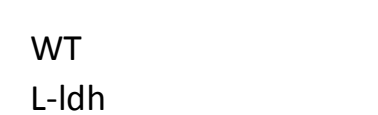 & 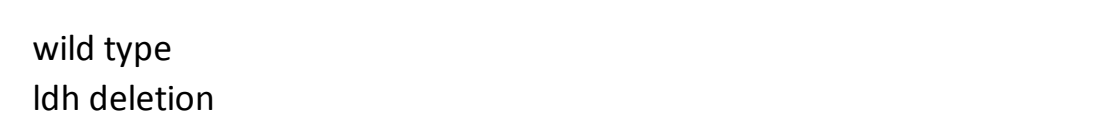 & $\begin{array}{l}75 \% \\
77 \% \\
79 \%\end{array}$ & $\begin{array}{l}1.6 \\
1.7\end{array}$ & & 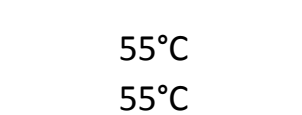 & $\begin{array}{l}\text { Shaw etal. } 2008 \\
\text { Shawe tal. } 2008\end{array}$ & $\begin{array}{l}\text { xylose, table } 51 \\
\text { xlyses tobalesi }\end{array}$ \\
\hline 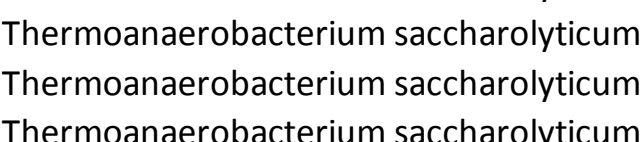 & 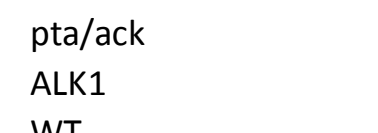 & 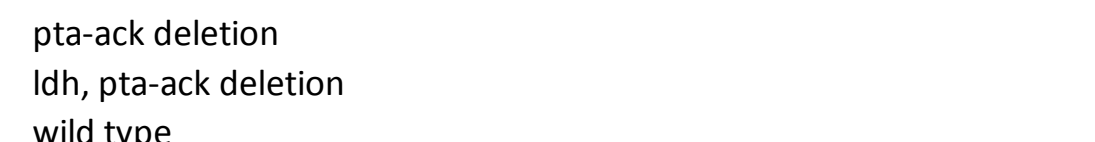 & $\begin{array}{l}100 \% \\
104 \% \\
\end{array}$ & 2.2 & & 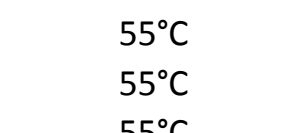 & $\begin{array}{l}\text { Shawe tel. } 2008 \\
\text { shawetal } 2008\end{array}$ & 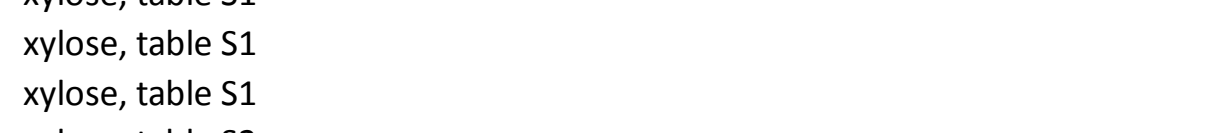 \\
\hline 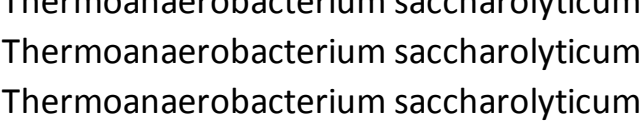 & 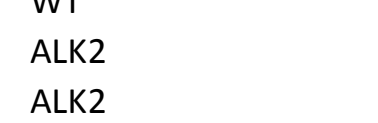 & 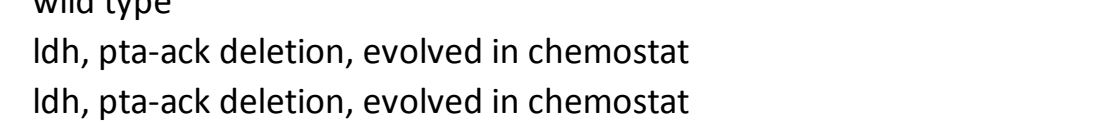 & 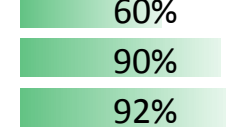 & $\begin{array}{rl} & 3.4 \\
5 & 5.5 \\
3.0 & \end{array}$ & 2.20 & 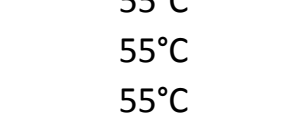 & 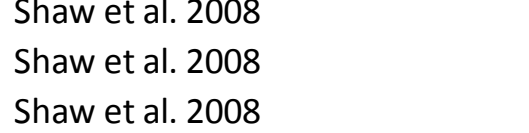 & 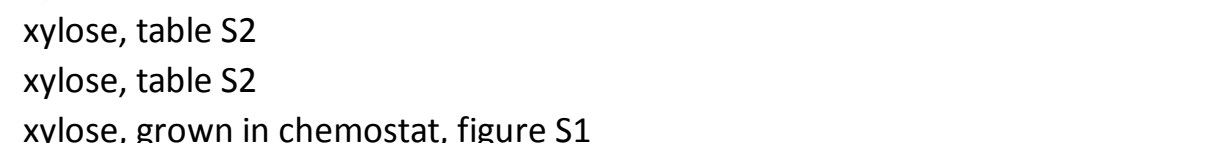 \\
\hline 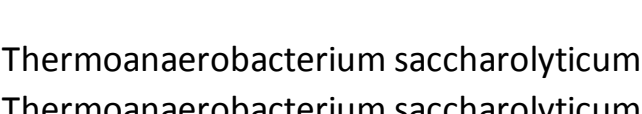 & wildtype & wild thpe & $58 \%$ & I 1.4 & & s5sc & Shaw etal. 2011 & cellobiose, table 1 \\
\hline 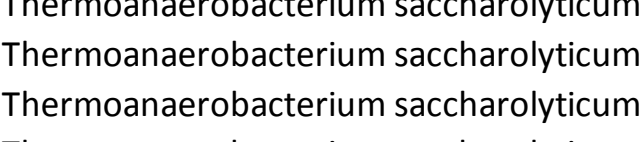 & 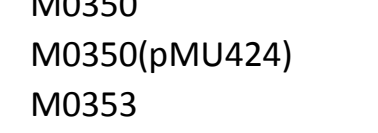 & 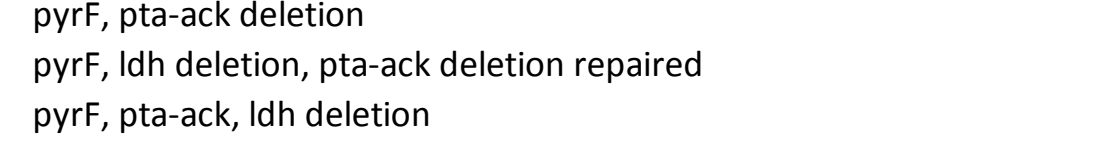 & 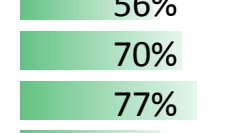 & $\begin{array}{l}0.7 \\
1.0 \\
1.0\end{array}$ & & 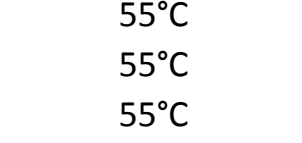 & 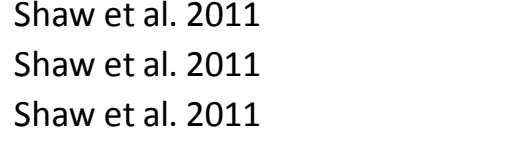 & 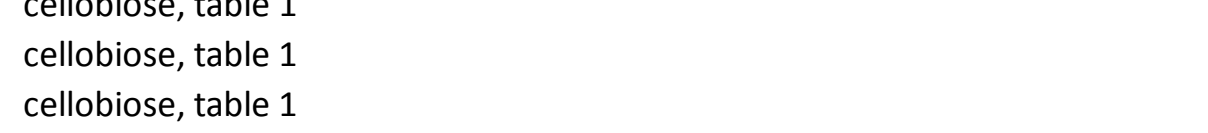 \\
\hline 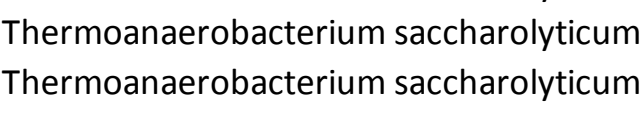 & M0355 & 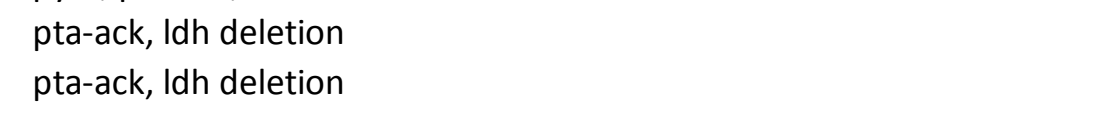 & $\begin{array}{l}59 \% \\
99 \% \\
\end{array}$ & $\begin{array}{l}0.8 \\
-25.3 \\
-10\end{array}$ & 1.13 & $\begin{array}{c}55 \mathrm{c} \\
{ }_{55} \mathrm{c}\end{array}$ & $\begin{array}{l}\text { Shawe telal } 2011 \\
\text { Shawe eta } 2011\end{array}$ & 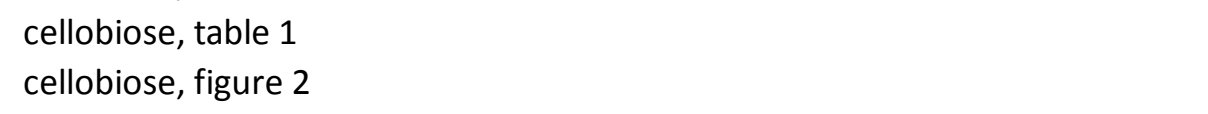 \\
\hline Thermoannerobabcterium saccharolyticum & rs485 & wild type & $477 \%$ & 1.2 & & 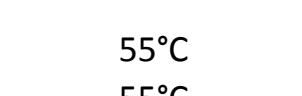 & Shaw etal. 2009 & cellobises, table 2 \\
\hline 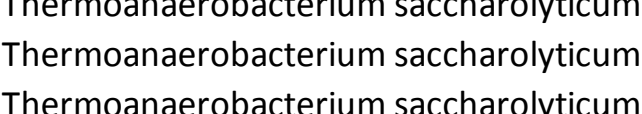 & 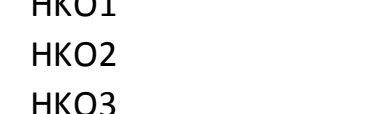 & 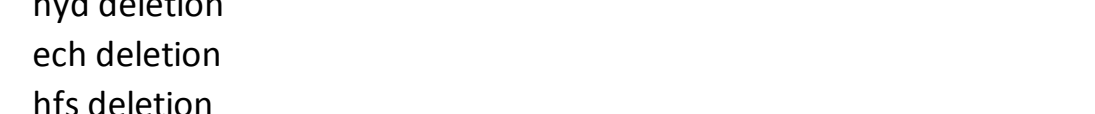 & 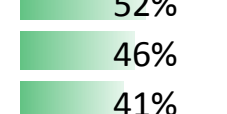 & $\begin{array}{l}1.3 \\
1.2 \\
09\end{array}$ & & 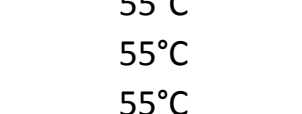 & 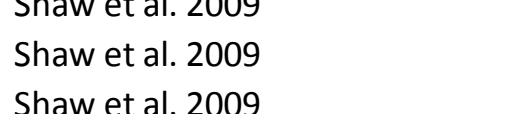 & 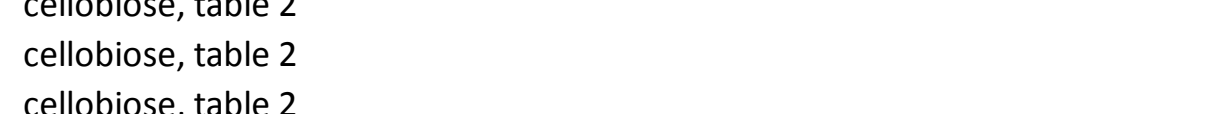 \\
\hline 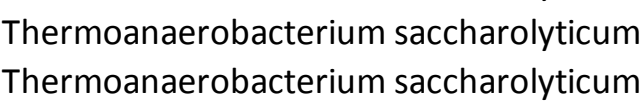 & $\begin{array}{l}\text { HKO4 } \\
\text { HKO5 }\end{array}$ & $\begin{array}{l}\text { ech, hyd deletion } \\
\text { echth hhs dselotion }\end{array}$ & $\begin{array}{c}60 \% \\
39 \% \\
5 \%\end{array}$ & $\begin{array}{l}1.5 \\
0.8\end{array}$ & & 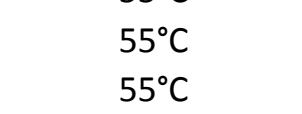 & $\begin{array}{l}\text { Shaw etal. } 2009 \\
\text { Shaw wat. } 2009\end{array}$ & $\begin{array}{l}\text { cellobiose, table } 2 \\
\text { cellobises tabale }\end{array}$ \\
\hline 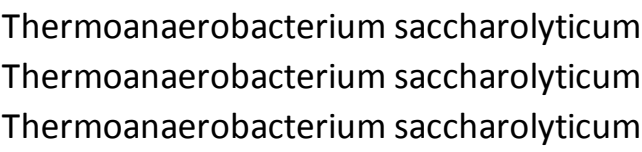 & 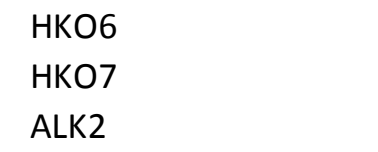 & 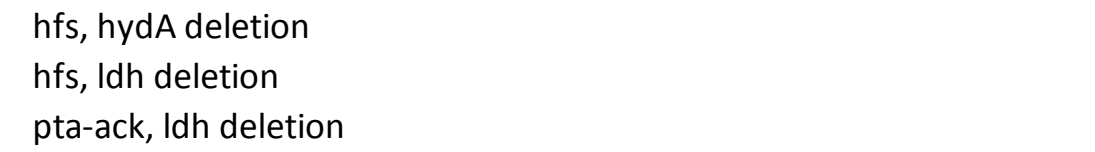 & $\begin{array}{l}32 \% \\
601 \% \\
601 \% \\
\end{array}$ & $\begin{array}{ll}0.5 \\
0.8 \\
2.5\end{array}$ & & $\begin{array}{ll}s 5 \mathrm{c} \\
\mathrm{ssc}\end{array}$ & 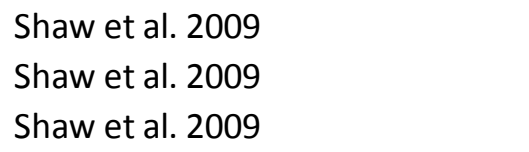 & 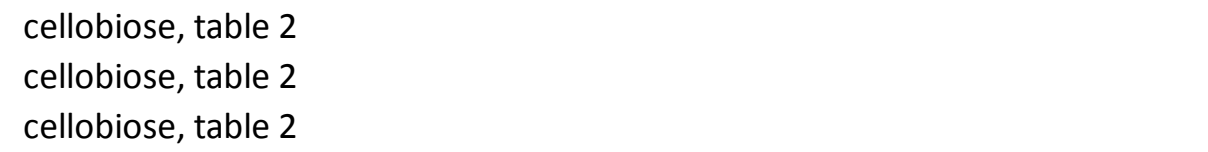 \\
\hline 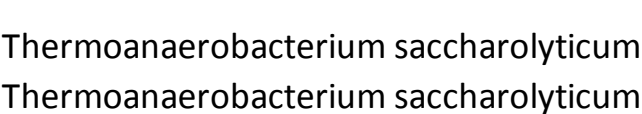 & $\begin{array}{l}\text { Mo863 } \\
\text { M1051 }\end{array}$ & 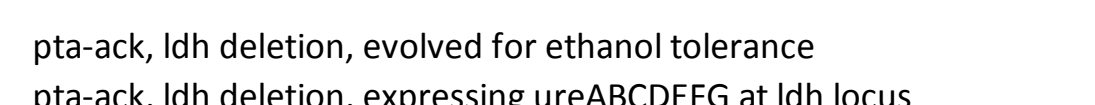 & $796 \%$ & $\begin{aligned} 3.8 \\
126\end{aligned}$ & & 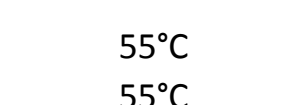 & $\begin{array}{l}\text { Shaw etal. } 2012 \\
\text { che } 12012\end{array}$ & $\begin{array}{l}\text { cellobise, table } 2 \\
\text { cellobios trab } 2\end{array}$ \\
\hline 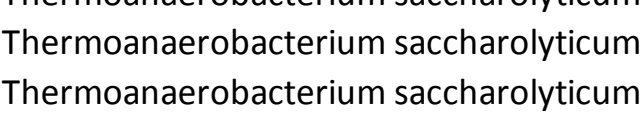 & $\begin{array}{l}\text { M1051 } \\
\text { M10512 }\end{array}$ & 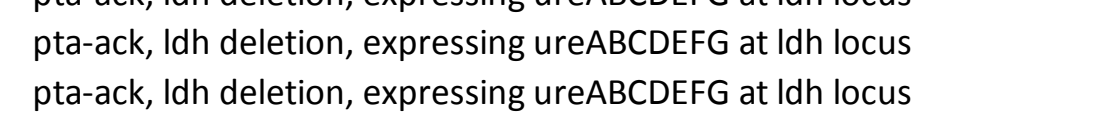 & $\begin{array}{l}88 \% \\
83 \% \\
836\end{array}$ & $\begin{array}{ll}543 \\
12.6\end{array}$ & 0.72 & 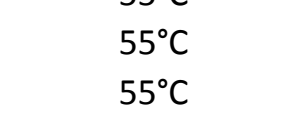 & $\begin{array}{l}\text { Shaw etal. } 2012 \\
\text { Shaw et al. } 2012\end{array}$ & $\begin{array}{l}\text { cellobiosis, fivure } 3 \\
\text { cellobise fivure } 2\end{array}$ \\
\hline Thermaanaerobacterium saccharolyticum & $M_{1442}$ & 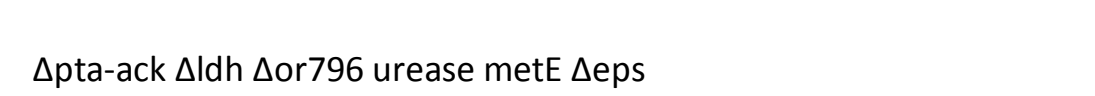 & $90 \%$ & $=610$ & 2.13 & ${ }_{55}^{5 \mathrm{c}}$ & Herring etal 2012 & cellulus with added enryme, dataf from text \\
\hline Thermoanaeroboacter mathranii & B61 & wild type & $62 \%$ & 1.6 & & $700 \mathrm{c}$ & Yao and Mikkelsen 2010a & growhth on xylose, aclculated from datat from figure 3 \\
\hline 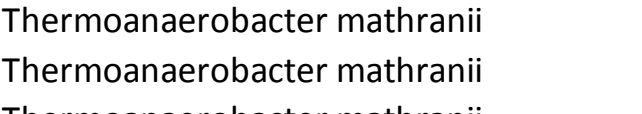 & 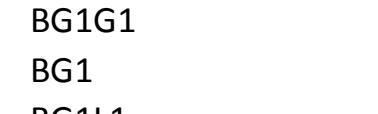 & 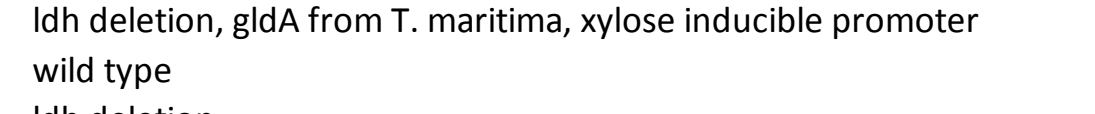 & $\frac{836}{68 \%}$ & $\begin{array}{l}1.8 \\
1.6\end{array}$ & & $\begin{array}{ll}70 \mathrm{c} \\
70 \mathrm{c}\end{array}$ & 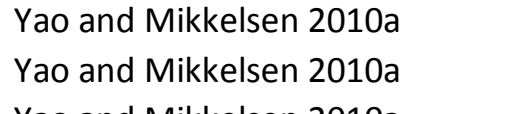 & 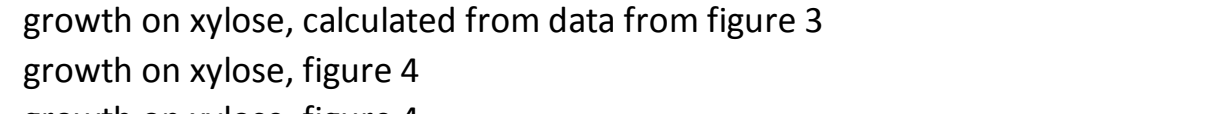 \\
\hline 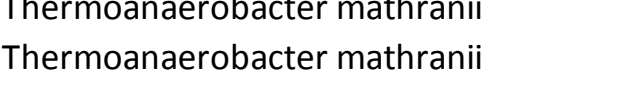 & B6161 & 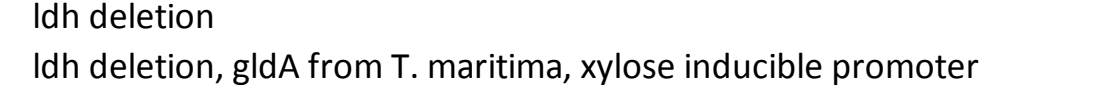 & ${ }^{3064}$ & 2.8 & & toc & 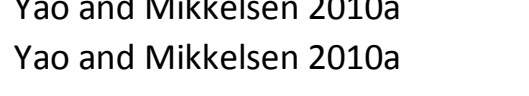 & 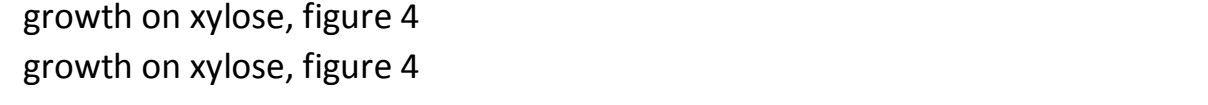 \\
\hline Thermoanaeroboacter mathranii & B6111 & Iand deletion & $83 \%$ & If 4.6 & & $700^{\circ}$ & Georgieva et al. 2008 & gulucose and x/lose, from table 1 \\
\hline 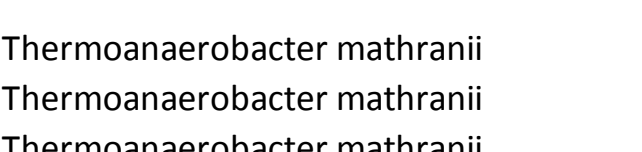 & $\begin{array}{l}861 \\
86111 \\
86111\end{array}$ & 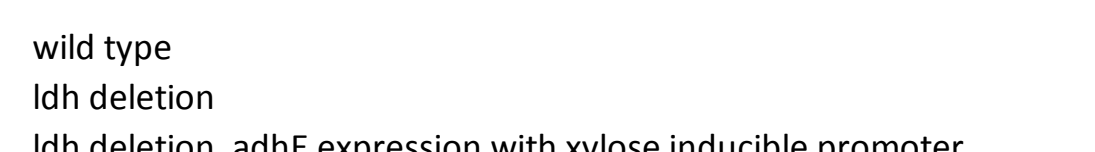 & $\begin{array}{l}84 \% \\
8786 \\
9850\end{array}$ & $\begin{array}{ll}2.3 \\
2.4 \\
2.4\end{array}$ & & 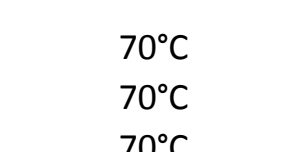 & 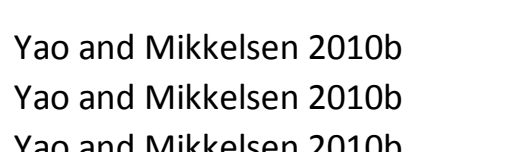 & $\begin{array}{l}\text { xylose, from table } 4 \\
\text { xylose, trom table } 4 \\
4\end{array}$ \\
\hline 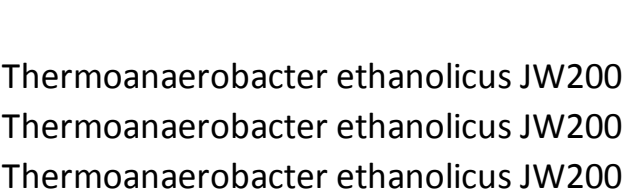 & 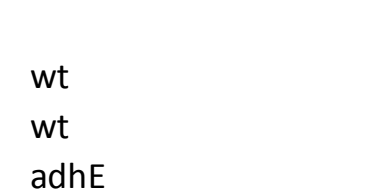 & $\begin{array}{l}\text { wil trpe } \\
\text { widtrpope } \\
\text { ahd Fever }\end{array}$ & 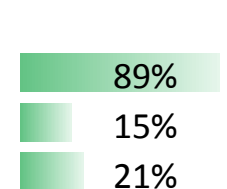 & $\begin{array}{l}3.6 \\
0.3 \\
0.4\end{array}$ & & $\begin{array}{l}72 \mathrm{c} \\
\text { sis } \\
45 \mathrm{C}\end{array}$ & 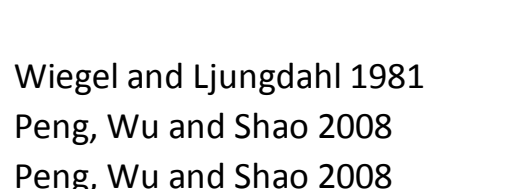 & 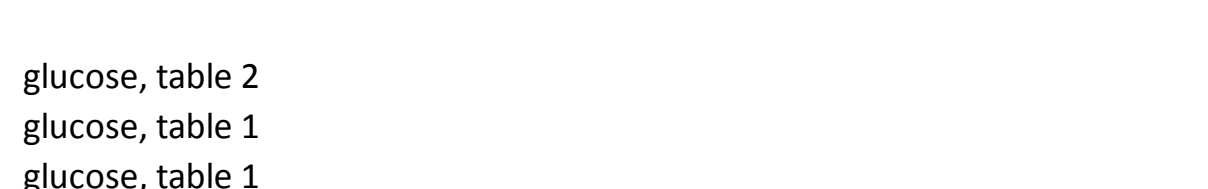 \\
\hline 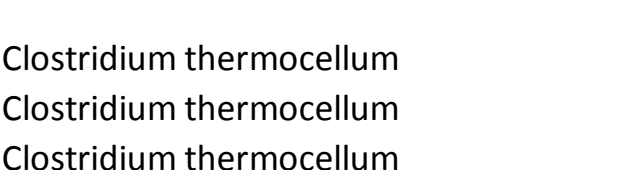 & 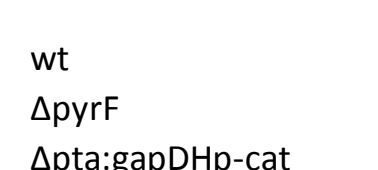 & 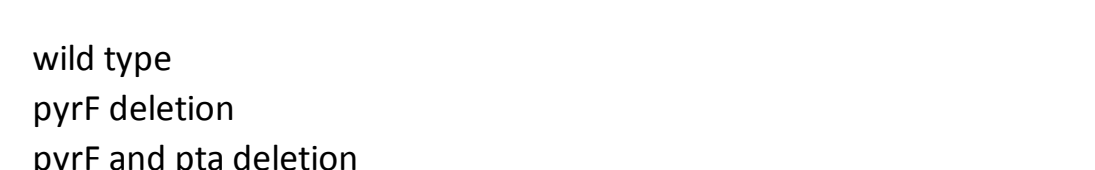 & $\begin{array}{l}24 \% \\
250 \% \\
30 \% 5\end{array}$ & $\mid \begin{array}{l}0.7 \\
0.7 \\
0.8\end{array}$ & & 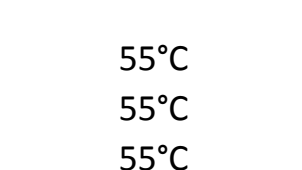 & 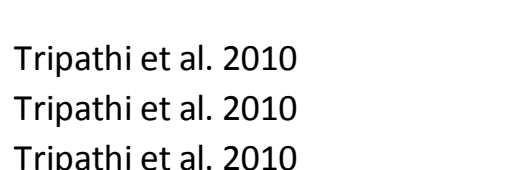 & 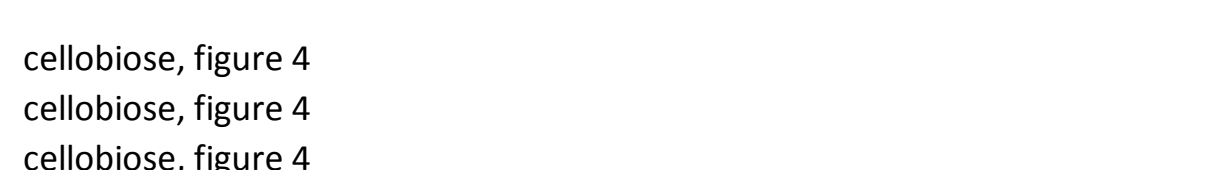 \\
\hline Clostridium thermocellum & м0003 & wt & $=12 \%$ & 1.4 & & ${ }^{550 \mathrm{c}} \mathrm{c}$ & Argyros e eta. 2011 & cellulose, figure 3 \\
\hline $\begin{array}{l}\text { Cosostridium thermoceclum } \\
\text { costridium thermocellum }\end{array}$ & M1375 & $\begin{array}{l}\text { hopt } \\
\text { hotddh }\end{array}$ & 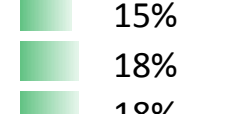 & $\begin{array}{l}1.6 \\
2.0\end{array}$ & & $\begin{array}{l}55 \mathrm{C} \\
\mathrm{ssc}^{\circ}\end{array}$ & 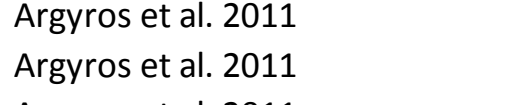 & $\begin{array}{l}\text { celluloses fifure } 3 \\
\text { celluose, figure } 3\end{array}$ \\
\hline 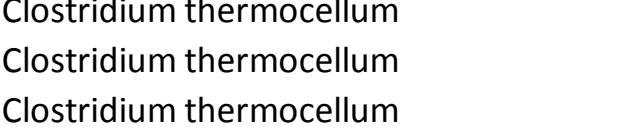 & 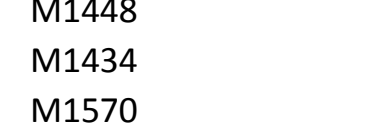 & 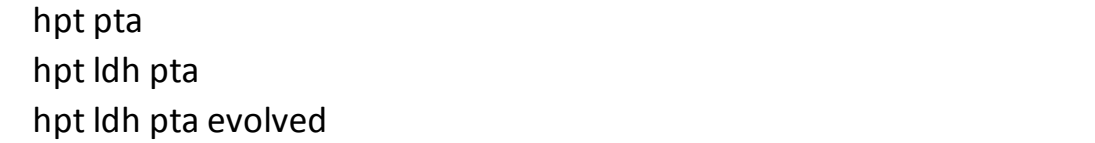 & $\begin{array}{l}128 \% \\
\text { 128\% } \\
51 \% \\
51 \%\end{array}$ & $\begin{array}{l}2.0 \\
2.6 \\
5.6\end{array}$ & & 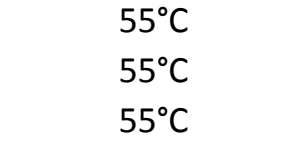 & 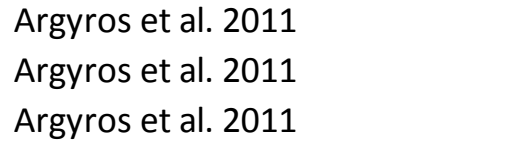 & 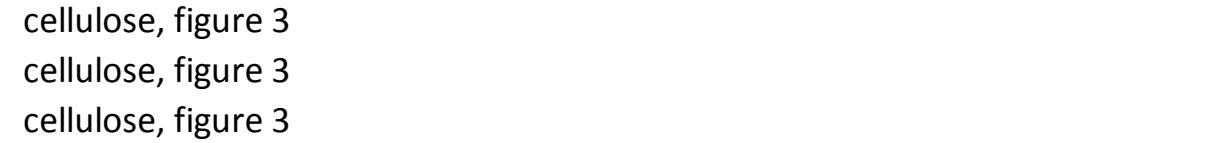 \\
\hline Clostridium thermocellum & M1726 & Ahpt AspoOA & $=17 \%$ & 0.4 & & $55^{5} \mathrm{C}$ & van der veen etat 2013 & cellobisse, table 2 \\
\hline $\begin{array}{l}\text { clostridium thermocecllum } \\
\text { colstridium thermocellum }\end{array}$ & $\begin{array}{l}\text { M1630 } \\
\text { M1725 }\end{array}$ & 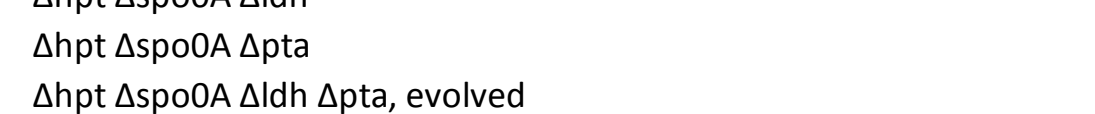 & 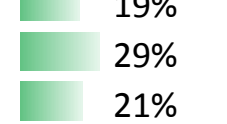 & 0.8 .8 & & 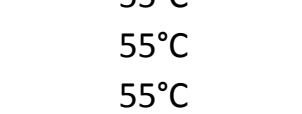 & 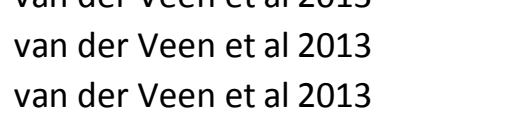 & 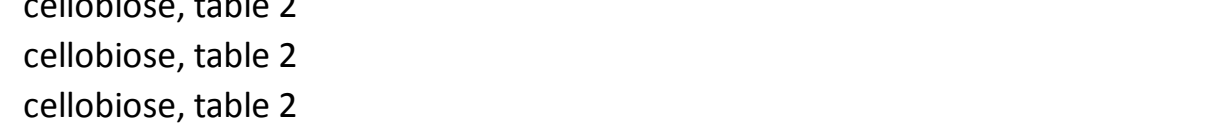 \\
\hline $\begin{array}{l}\text { Clostridium thermocellum } \\
\text { colstridum thermocelum }\end{array}$ & 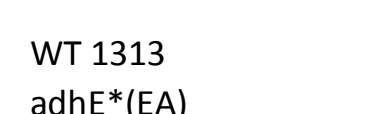 & $\begin{array}{l}\text { wild type } \\
\text { mutured anh }\end{array}$ & $=29 \%$ & $\begin{array}{l}0.8 \\
0.0\end{array}$ & & 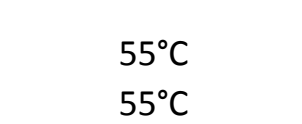 & $\begin{array}{l}\text { Biswas etat } 2014 \\
\text { Bussast }\end{array}$ & 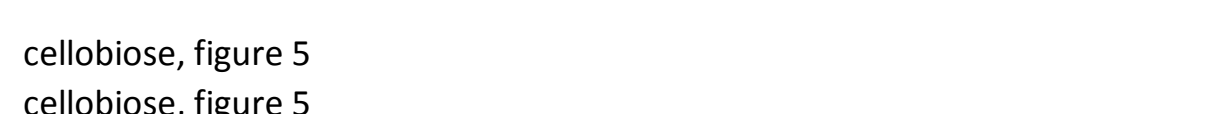 \\
\hline Clostridium thermocellum & & mutrated adh Enand Ith deletion & & & & & Biswas etala. 2014 & cellobiose, figure 5 \\
\hline 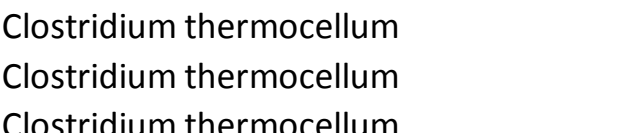 & 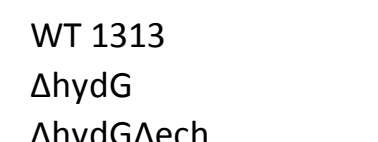 & $\begin{array}{l}\text { Wild thpe } \\
\text { deletito o fall hydrogenasese except ech } \\
\text { delation }\end{array}$ & $\begin{array}{c}34 \% \\
53 \% \\
6 . \%\end{array}$ & $\begin{array}{ll}0.9 \\
1.4 \\
1 .\end{array}$ & & 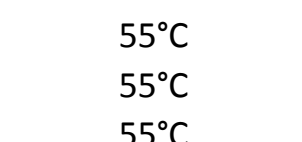 & 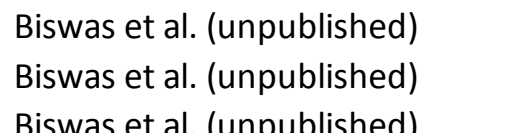 & $\begin{array}{l}\text { cellobiose } \\
\text { celobiose } \\
\text { celutioge }\end{array}$ \\
\hline Closstridum thermocellum & ${ }_{\text {wT }}$ & wildtppe & $34 \%$ & 0.9 & & 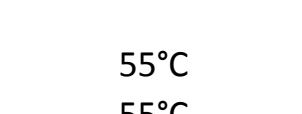 & Deng etal. 2013 & $\begin{array}{l}\text { cellobiose, figure } 3 \text { from corrigendum } \\
\text { ellubsen }\end{array}$ \\
\hline 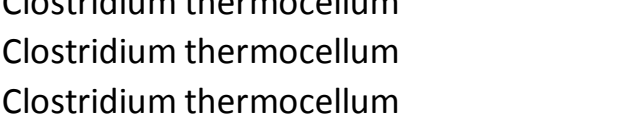 & 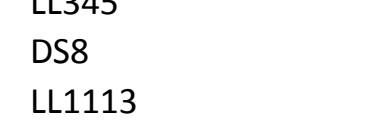 & 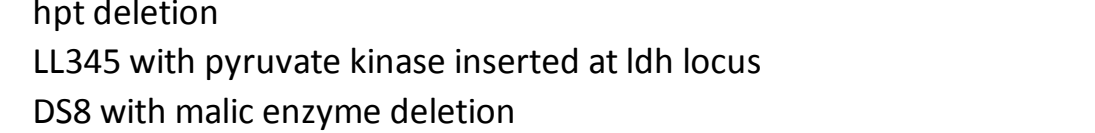 & 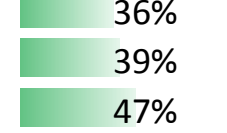 & 畩. & & 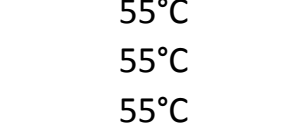 & 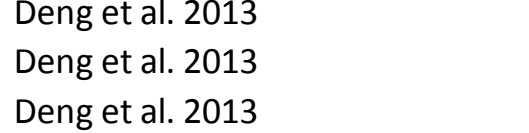 & 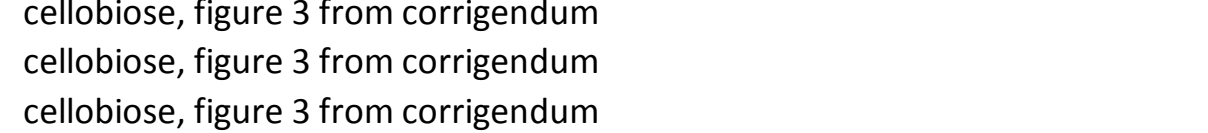 \\
\hline 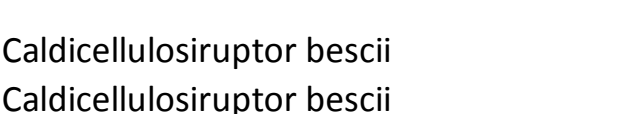 & $\begin{array}{l}\text { Jw68вo01 } \\
\text { Jc6818 }\end{array}$ & $\begin{array}{l}\text { wild type } \\
\text { luh heletion }\end{array}$ & $\frac{0 \%}{0 \%}$ & $\begin{array}{l}0.0 \\
0.0\end{array}$ & & 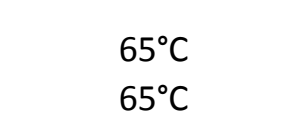 & $\begin{array}{l}\text { Chung etal } 2014 \\
\text { Chung tala } 2014\end{array}$ & 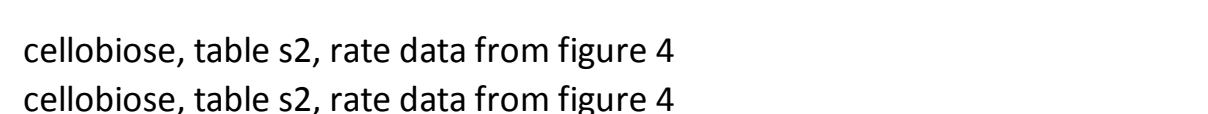 \\
\hline Caldicellulosiruptor bescii & JwCBO32 & Iald deletion and adhE Everexpression & & & & & Chung etal. 2014 & cellobiose, table s2, rate datat from figure 4 \\
\hline 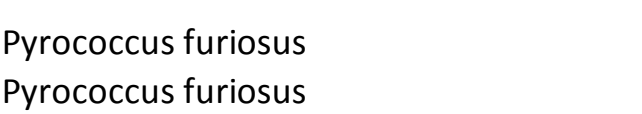 & come & 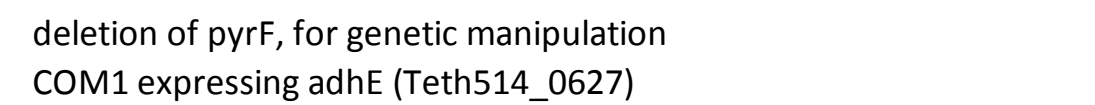 & $\begin{array}{l}2 \% \\
4 \%\end{array}$ & $\begin{array}{l}0.05 \\
0.10 \\
0.10\end{array}$ & & 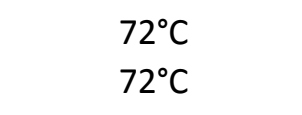 & $\begin{array}{lll}\text { Basene etal } 2.214 \\
\text { Basan etala } 2014\end{array}$ & 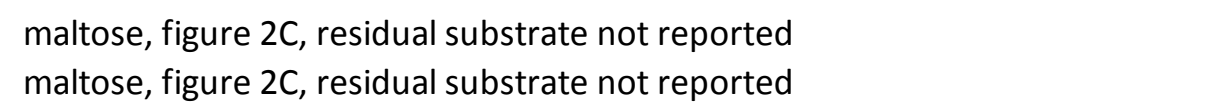 \\
\hline 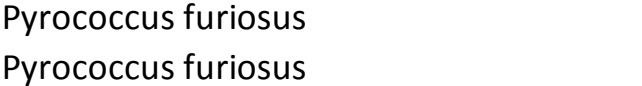 & EA & 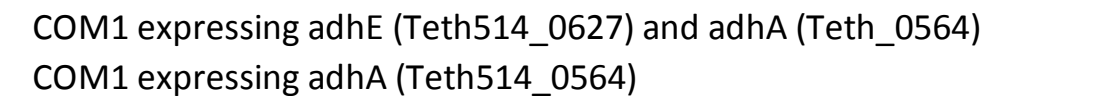 & & $\begin{array}{c}0.45 \\
0.95\end{array}$ & 0.02 & 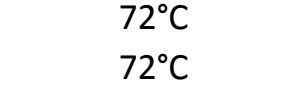 & $\begin{array}{lll}\text { Basene tala. } 2014 \\
\text { Bassen etal } 2014\end{array}$ & 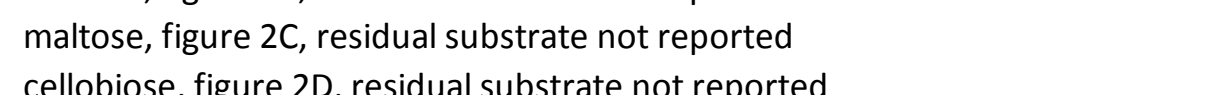 \\
\hline
\end{tabular}




\section{Figure 1 caption}

A, B, C, G are from Carere C.R., Rydzak T., Verbeke T.J., Cicek N., Levin D.B., Sparling R. 2012. Linking genome content to biofuel production yields: a meta-analysis of major catabolic pathways among select H2 and ethanol-producing bacteria. BM C M icrobiol. 12:295

D, E, are from Verbeke TJ, Zhang X, Henrissat B, Spicer V, RydzakT, Krokhin OV, Fristensky B, Levin DB, Sparling R. 2013. Genomic Evaluation of Thermoanaerobacter spp. for the Construction of Designer Cocultures to Improve Lignocellulosic Biofuel Production PloS One 8: e593625758.

F, while based on Shaw et al., 2008, was complemented by manual search and BLAST to confirm that the $\mathrm{NFOR}$ is related to $\mathrm{nfnAB}$, that the hyd is related to the bifurcating hydrogenases. A further Fe-Fe hydrogenase was observed in the genome. The absence of other genes was confirmed both from the annotation as well as BLAST anchored in C. thermocellum and T. thermohydrosulfuricum WC1, including lack of membrane bound RNF-type NFO.

nfnAB. Presence/ absence was based on Wang S, Huang H, M oll J, Thauer RK, 2010 NADP+reduction with reduced ferredoxin and NADP+reduction with NADH are coupled via an electron bifurcating enzyme complex in Clostridium kluyveri. J. Bacteril. 192: 5115-5123. For C. thermocellum it was through the analysis by Rydzak, T., Grigoryan, M., Cunningham, Z. J., Krokhin, O. V., Ezzati, P., Cicek, N. et al. Sparling, R. (2014). Insights into electron flux through manipulation of fermentation conditions and assessment of protein expression profiles in Clostridium thermocellum. Appl. Microbiol. Biotechnol. 98: 6497-6510. With respect to $\mathbf{B}$ and $\mathbf{F}$ it was through BLAST and side by side location of both genes needed for nfnAB. The annotated genes in F corresponding to nfnAB were TheetDRAFT_0838 and 0839.

Lower case (a) for PDC is based on K. M a, A. Hutchins, S. J. S. Sung, and M. W. W. Adams, "Pyruvate ferredoxin oxidoreductase from the hyperthermophilic archaeon, Pyrococcus furiosus, functions as a CoA-dependent pyruvate decarboxylase," Proceedings of the National Academy of Sciences of the United States of America, vol. 94, no. 18, pp. 9608-9613, 1997.

0. polymorpha was based on Ravin N V, Eldarov M a, Kadnikov V V, Beletsky A V, Schneider J, Mardanova ES, Smekalova EM, Zvereva MI, Dontsova $\mathrm{O}$ a, Mardanov A V, et al.: Genome sequence and analysis of methylotrophic yeast Hansenula polymorpha DL1. BM C Genomics 2013, 14:837.

Amino acid synthesis indicates organisms where this phenotype has been observed. Question marks indicate that amino acid production has not been reported in these organisms

\section{Table 1 caption}

Theoretical yield calculations assume that one glucose (or equivalent) molecule can be converted into two ethanol molecules, and one xylose molecule can be converted into 5/3 ethanol molecules. In cases where the amount of substrate consumed was not reported, it was assumed that the substrate was completely consumed.

Rate was calculated only when time-course data was available. 